Article

\title{
Acoustic Mapping of Submerged Stone Age Sites-A HALD Approach
}

\author{
Ole Grøn ${ }^{1,2, *}\left(\mathbb{D}\right.$, Lars Ole Boldreel ${ }^{1}$, Morgan F. Smith ${ }^{3,4} \oplus$, Shawn Joy ${ }^{4,5}$, Rostand Tayong Boumda ${ }^{6,7}$, \\ Andreas Mäder ${ }^{8}$, Niels Bleicher ${ }^{8}{ }^{1}$, Bo Madsen ${ }^{9}$, Deborah Cvikel ${ }^{10}{ }^{(\mathbb{D},}$, Björn Nilsson ${ }^{11}$, Arne Sjöström ${ }^{11}$, \\ Ehud Galili ${ }^{12}$, Egon Nørmark ${ }^{13}{ }^{(0}$, Changqing Hu ${ }^{14}$, Qunyan Ren ${ }^{15}$, Philippe Blondel ${ }^{16}{ }^{\circ}$, Xing Gao ${ }^{17}$, \\ Petra Stråkendal ${ }^{18}$ and Antonio Dell'Anno ${ }^{19}$ (i)
}

Citation: Grøn, O.; Boldreel, L.O.; Smith, M.F.; Joy, S.; Tayong Boumda, R.; Mäder, A.; Bleicher, N.; Madsen,

B.; Cvikel, D.; Nilsson, B.; et al. Acoustic Mapping of Submerged Stone Age Sites-A HALD Approach. Remote Sens. 2021, 13, 445. https:// doi.org/10.3390/rs13030445

Academic Editors: Carl Philipp Lipo and Magaly Koch

Received: 1 December 2020

Accepted: 21 January 2021

Published: 27 January 2021

Publisher's Note: MDPI stays neutral with regard to jurisdictional claims in published maps and institutional affiliations.

Copyright: (c) 2021 by the authors. Licensee MDPI, Basel, Switzerland. This article is an open access article distributed under the terms and conditions of the Creative Commons Attribution (CC BY) license (https:// creativecommons.org/licenses/by/ $4.0 /$ )
1 Department of Geosciences and Natural Resource Management, University of Copenhagen, 1250 Copenhagen, Denmark; lob@ign.ku.dk

2 Culture \& Preservation, 9690 Fjerritslev, Denmark

3 Department of Social, Cultural and Justice Studies, The University of Tennessee, Chattanooga, TN 37403, USA; Morgan-F-Smith@utc.edu

4 The Archaeological Research Cooperative Inc., Tallahassee, FL 32305, USA; ssjoy45@yahoo.com

5 SEARCH Inc., Tallahassee, FL 32305, USA

6 Acoustics \& Environmental HydroAcoustics Lab, Université Libre de Bruxelles (ULB), 1050 Brussels, Belgium; rostand.tayongboumda@beds.ac.uk

7 Faculty of Creative Arts, Technologies and Science, University of Bedfordshire, Luton LU1 3JU, UK

8 Unterwasserarchäologie/Dendrochronologie Zürich, Amt für Stadtebau, 8008 Zürich, Switzerland; Andreas.Maeder2@zuerich.ch (A.M.); niels.bleicher@zuerich.ch (N.B.)

9 East Jutland Museum, 8900 Randers, Denmark; blademaker51@gmail.com

10 Leon Recanati Institute for Maritime Studies, University of Haifa, Haifa 3498838, Israel; dcvikel@research.haifa.ac.il

11 Department of Archaeology and Ancient History, Lund University, 22100 Lund, Sweden; bjorn.nilsson@ark.lu.se (B.N.); arne.sjostrom@ark.lu.se (A.S.)

12 The Zinman Institute of Archaeology, University of Haifa, Haifa 3498838, Israel; galilish@netvision.net.il

13 Department of Geoscience, Aarhus University, 8000 Aarhus, Denmark; en@geo.au.dk

14 Shanghai Acoustics Laboratory, Institute of Acoustics, Chinese Academy of Sciences, Shanghai 201815, China; hchq@mail.ioa.ac.cn

15 Institute of Acoustics, Chinese Academy of Sciences, Beijing 100190, China; renqunyan@mail.ioa.ac.cn

16 Department of Physics, University of Bath, Bath BA2 7AY, UK; pyspb@bath.ac.uk

17 Key Laboratory for Vertebrate Evolution and Human Origins,

The Institute of Vertebrate Paleontology and Paleoanthropology, The Chinese Academy of Sciences,

Beijing 100044, China; gaoxing@ivpp.ac.cn

18 Länsstyrelsen i Blekinge län, 37186 Karlskrona, Sweden; petra.strakendal@lansstyrelsen.se

19 Department of Life and Environmental Sciences (DiSVA), Università Politecnica delle Marche (UNIVPM), 60131 Ancona, Italy; a.dellanno@univpm.it

* Correspondence: olegron111@gmail.com

Abstract: Acoustic response from lithics knapped by humans has been demonstrated to facilitate effective detection of submerged Stone Age sites exposed on the seafloor or embedded within its sediments. This phenomenon has recently enabled the non-invasive detection of several hitherto unknown submerged Stone Age sites, as well as the registration of acoustic responses from already known localities. Investigation of the acoustic-response characteristics of knapped lithics, which appear not to be replicated in naturally cracked lithic pieces (geofacts), is presently on-going through laboratory experiments and finite element (FE) modelling of high-resolution 3D-scanned pieces. Experimental work is also being undertaken, employing chirp sub-bottom systems (reflection seismic) on known sites in marine areas and inland water bodies. Fieldwork has already yielded positive results in this initial stage of development of an optimised Human-Altered Lithic Detection (HALD) method for mapping submerged Stone Age sites. This paper reviews the maritime archaeological perspectives of this promising approach, which potentially facilitates new and improved practice, summarizes existing data, and reports on the present state of development. Its focus is not reflection seismics as such, but a useful resonance phenomenon induced by the use of high-resolution reflection seismic systems. 
Keywords: acoustic mapping; cultural heritage management; lithic artefacts; underwater archaeology; underwater survey

\section{Introduction}

The increasing focus in archaeology on early human development, supported by, for example, improved and faster methods for the analysis of ancient DNA, suffers a central problem in that a large part of the relevant palaeo-landscape is today submerged and difficult to detect with existing maritime archaeological methods. Further underlining the significance of this obstacle is an increasing body of evidence suggesting that a coastal lifestyle with a maritime economy played a central role in human development, reproduction and mobility in the course of human history [1-10]. Since the sea level has been lower than today for $90 \%$ of human history and fell to around $-120 \mathrm{~m}$ at the height of glaciations, we lack data from up to $9 \%$ of the Earth's surface, representing highly productive prehistoric coastal ecosystems. This undiscovered land must have been of huge significance for early human dispersal and subsistence [11-15]. In Europe, where the study of Palaeolithic archaeology originated, submerged areas from the glacial periods correspond to as much as $40 \%$ of the present land area [16]. We may therefore be missing the central part of the picture, including an understanding of Palaeolithic cultures, their subsistence strategies, and population dynamics (e.g., Figure 1).

Large quantities of osteological material recovered off the continental coasts of northwest Europe and the Northeast United States document extensive megafauna in these now submerged coastal areas during the latter part of the most recent glaciation, including the Last Glacial Maximum. In combination with the available marine resources, the ecosystem this reflects would have been able to support a significant hunter-gatherer population with a coastal orientation. We can therefore expect there to have been human habitation in a significant proportion of the ice-free coastal zones in the formerly glaciated areas, similar to that demonstrated by the recent Inuit adaptation to Arctic coastal zones [11,17-21]. The issues related to these data gaps distort not only the archaeological record for the Old World, but affect that of the New World, too. Indeed, the peopling of the Western Hemisphere is most likely written on submerged lands in a way that is not yet fully understood [22-29]. Unequivocal archaeological sites have been identified in the New World that date back 14,500 years, i.e., almost a millennium before the advent of the widespread Clovis culture, and almost two millennia before the ice-free corridor from Beringia was an option for migration [27,30]. Models for the peopling of the Americas have recently shifted to involve coastal or maritime routes along now submerged coasts [22,29,31-35].

Social anthropological data indicate that more dynamic cultural groups tend to push their territories into areas of greater ecological productivity, such as marine coasts [35]. Sites found associated with submerged coastlines may therefore represent prehistoric subsistence economies and behavoural systems that deviate from coeval parallels investigated on dry land [13]. 


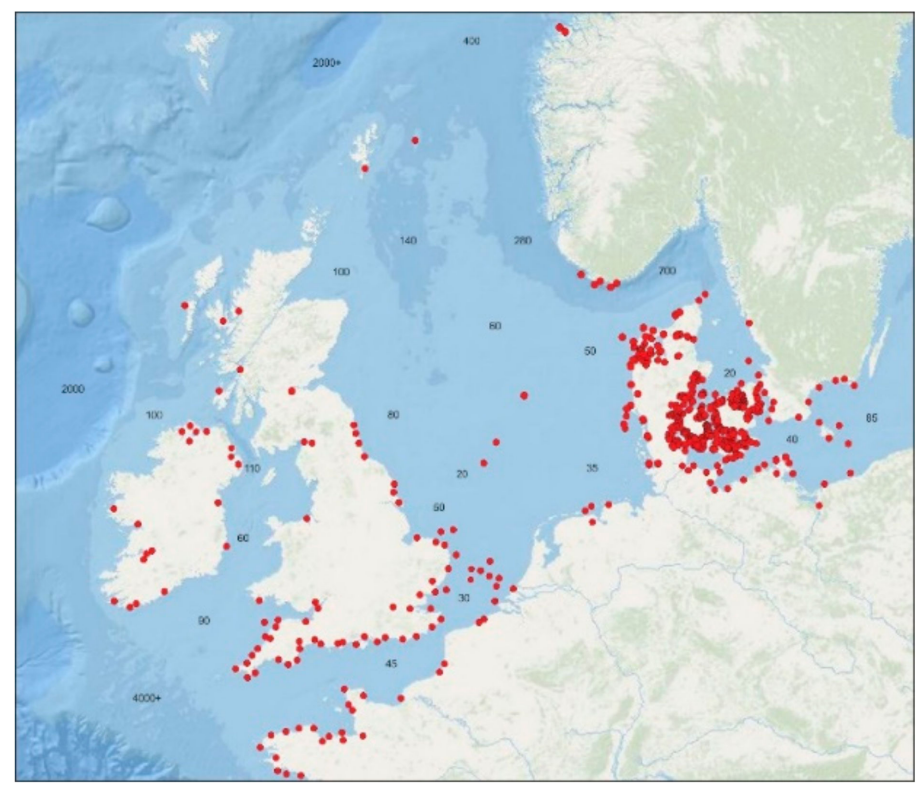

Figure 1. Recorded submerged Stone Age sites in northwest Europe. Depths given in meters. After Bailey et al. [36]. Graphic: Grøn.

Whatever the geographical focus, the efficient mapping and recording of submerged Stone Age sites/archaeological sites employing lithic knapping technology constitutes a central archaeological challenge. Submerged cultural deposits may be well preserved and intact if quickly buried, but they may also be difficult to detect and map through surveys focused on identifying bathymetrical/topographical settlement indicators [37-40]. Therefore, the development of a methodology that can map submerged Stone Age sites directly and efficiently, including buried sites, will represent a significant contribution to underwater archaeology. A major opportunity in this respect is the response to acoustic excitation obtainable from the knapped lithics that are the hallmark of the Stone Age, but not from naturally cracked lithic pieces [41,42]. This paper presents an innovative and cost-effective acoustic Human-Altered Lithic Detection (HALD) approach to mapping submerged Stone Age sites, which is currently under development. We do not yet know whether it can be used to detect all types of knapped lithic materials (flint, obsidian, chert, quartzite, andesite, radiolarite, etc.). However, the variety of knapped materials (described below) that have produced acoustic responses indicates general applicability. The HALD approach thus appears to have the potential to improve the management of prehistoric cultural heritage in advance of extensive offshore developments, such as wind farms, and harbour expansions, as well as to assist in the pursuit of myriad research agendas. Current data indicate that quantity of lithics and artifact burial depth within substrate are negligible variables under good recording conditions [43]. How other environmental variables, such as water density/salinity, temperature or burial substrate, may affect the acoustic response of knapped lithics is still unknown. However, our purpose here is to present a summary of existing data and new results of HALD testing, including all significant methodological contributors thus far, with the hope that this article will serve as the authoritative reference for the HALD method.

\section{Materials and Methods}

A wide spectrum of stone is suitable for the controlled detachment ('knapping') of 'flakes' or 'longer' blades from 'cores'. Detached flakes and blades can be used directly as tools, due to their sharp edges or points, or worked into specific tool types by the further detachment of smaller pieces by knapping. Ethnographic and experimental studies document the use of various knapping techniques, both pressure flaking and direct and indirect percussion, where the hammer can range from stone to antler, bone or wood [44,45]. 
Hammer percussion removes a flake or a blade of the striking platform and leaves a bulb of percussion with concentric waves on the inner ('ventral') side of the detached piece. These waves can be understood as a Hertzian cone derivate; Hertzian cones being the conical pieces shaped when, for instance, a projectile penetrates a glass plate. Soft-hammer percussion or pressure exerted by an elastic to partially plastic tool removes the rim of the striking platform and leaves a lip-fracture with concentric waves on the inner side of the detached piece [46,47].

When selecting stone suitable for flaking, an experienced knapper tests the sound produced by the raw material to assess its density and listen for possible flaws or fissures. During flintknapping, long flat 'bifaces' or large square axes change sound when lightly tapped, as their volume and cross-section change. During this process, the pieces are carefully supported and dampened to avoid vibrations and shock. The finished tool also has a characteristic sound. The sound characteristics of knapped lithic pieces can be used specifically for musical purposes in 'lithophones', such as the Vietnamese đàn đá. Archaeological finds of 'lithophones', comprised of several elongated stone pieces knapped to produce a series of specific tones, appear to date back around 4000 years [48].

Detached flakes and blades also have a tone or a resonance frequency. The sounds produced by thin, wide flakes and long, prismatic blades are distinct to the human ear. The latter have been demonstrated (in experiments by Madsen) to be good material for making xylophones. During the experimental production of long $(20$ to $35+\mathrm{cm})$ flint blades from prismatic cores, by indirect percussion with an antler punch, Madsen observed that after the blades were detached from their core they could produce a deep tone when knocked against the antler punch or the core support.

\subsection{Laboratory Testing and Finite Element Modelling}

The role of sound in relation to the knapping process is of course interesting, but its further implications are also potentially useful. Given that, when excited by tapping, detached lithics can produce what appear to be single tones or rather narrow frequency intervals, they may also resonate when excited by an acoustic signal within the relevant frequency intervals and, as a consequence, produce a measurable acoustic response, as already documented in the Bang \& Olufsen Sound Laboratory by Hugo Rasmussen in 1982 (Figures 2 and 3) [41].

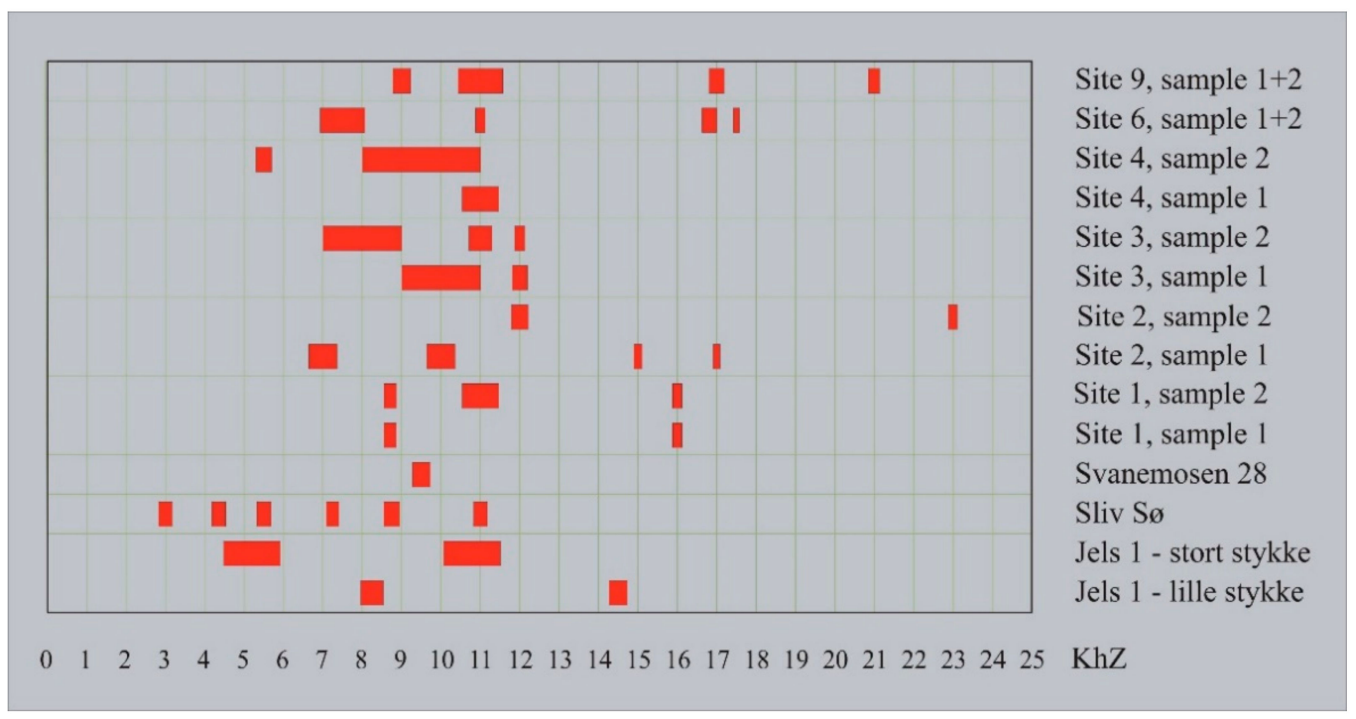

Figure 2. The resonance frequency peaks of Mesolithic and Late Palaeolithic flint blades measured in the Bang \& Olufsen Sound Laboratory. The two upper measurements each represent two separate blades. Measurements by Hugo Rasmussen 1982. Graphic: Grøn. 


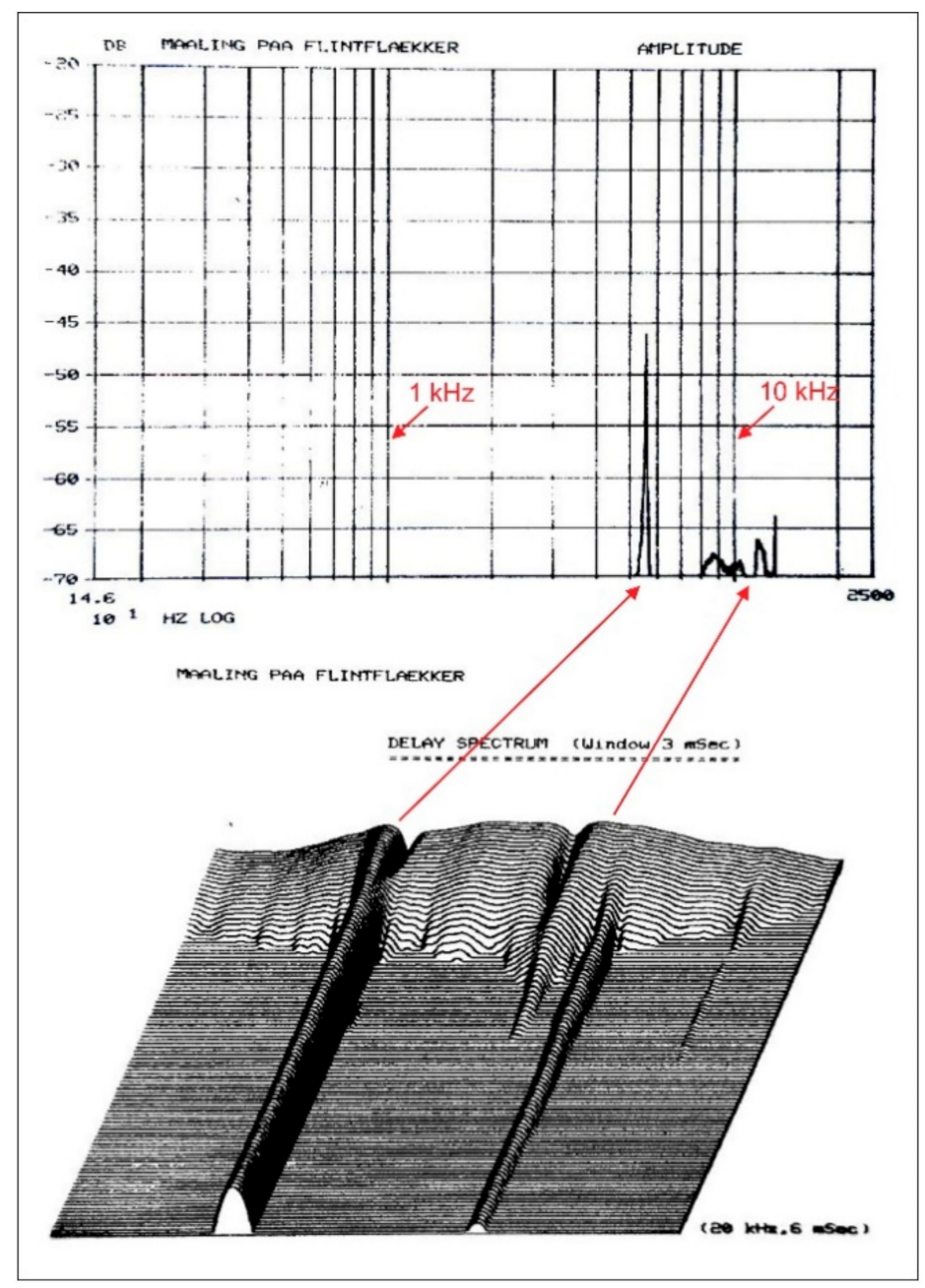

Figure 3. Detailed measurement of sample 2 from site 4 (see Figure 2) in the Bang \& Olufsen Sound Laboratory, showing the main peak of this flint blade between 5 and $6 \mathrm{kHz}$ (top), and the delay of its resonance over $6 \mathrm{msec}$ after excitation (bottom). Measurements by Hugo Rasmussen 1982. Graphic: Grøn.

These results were later independently replicated in the Wellbore Acoustic Lab at Texas A\&M University in two experiments undertaken in 2018. In one, a knapped Coastal Plains chert flake was affixed to a sound-neutral rod and then physically excited with a sharp blow from an impact hammer to simulate the sound produced during flintknapping. A receiver then measured the acoustic waves that radiated from the excited flake. The calculated acoustic transfer function further refined the peak resonances of the flake to 9.572, 13.830 and $23.140 \mathrm{kHz}$.

In the second experiment, a knapped Coastal Plains chert core was placed $1 \mathrm{~m}$ away from an emitter (a loudspeaker) and a receiver (a microphone) positioned $2 \mathrm{~cm}$ apart. The loudspeaker was programmed to emit sine burst signals with centre frequencies ranging from 4 to $13 \mathrm{kHz}$. The acoustic waves travelled from the speaker to the chert core and the microphone detected and measured the resulting acoustic excitation signals. The receiver detected two auto-correlation peaks at approximately $0 \mathrm{~m}$ and $2 \mathrm{~m}$ (Figure 4): The latter peak, at a wave travel distance of $2 \mathrm{~m}$, indicates that the acoustic response of the lithic piece was detected at a distance of $1 \mathrm{~m}$. It is interesting that in this experiment both debitage (i.e., flakes, blades etc.) and a core responded to acoustic signals within the same frequency intervals. This points to that not only unmodified debitage (blades and flakes) but also tools such as for instance projectile heads, knives, and scrapers, shaped by further modification of these, respond acoustically. 


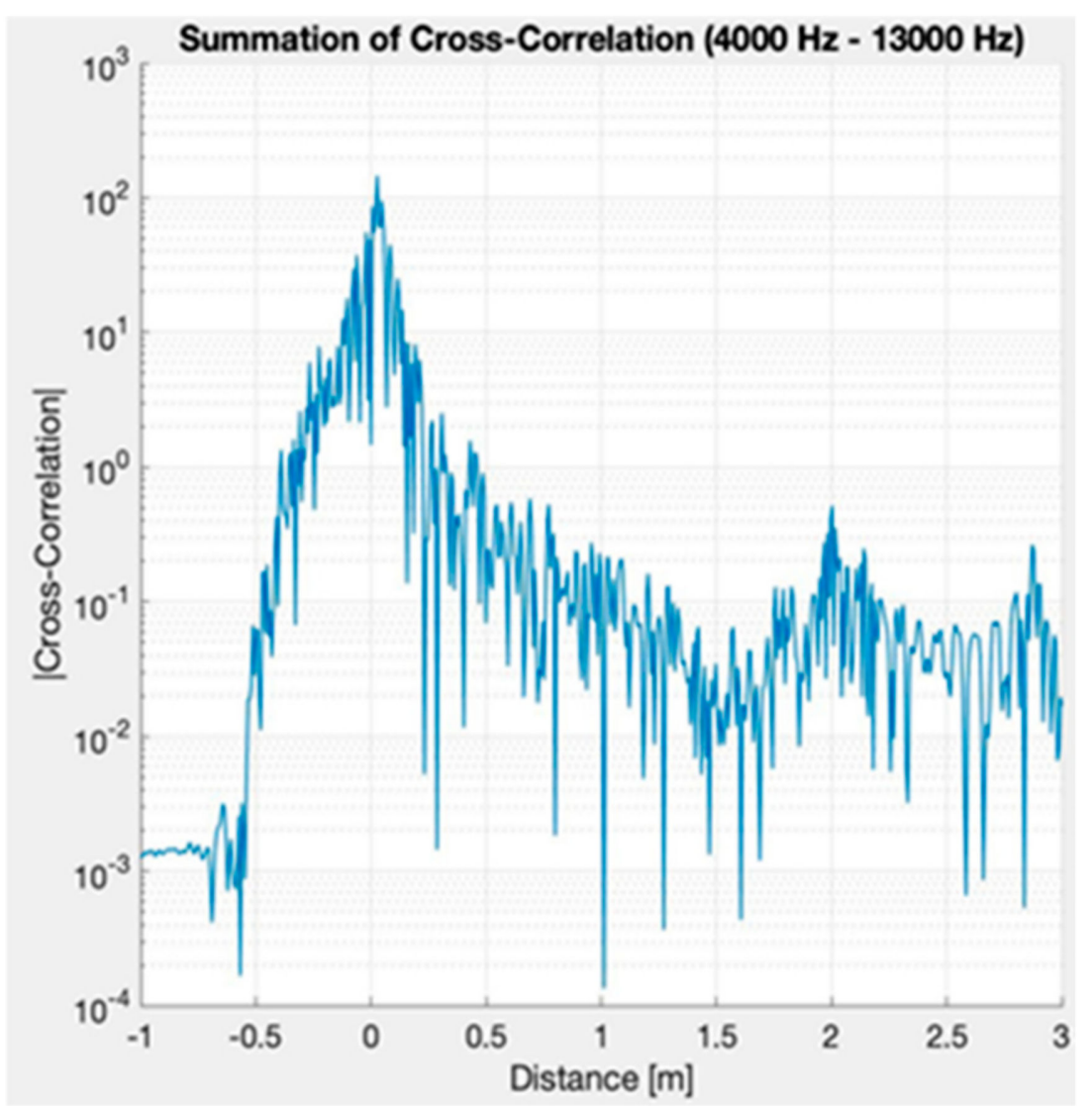

Figure 4. The measurement from the acoustic resonance tests on a knapped Coastal Plains core at the Wellbore Acoustic Laboratory at Texas A\&M University, 2018. The receiver detected two auto-correlation peaks at approximately $0 \mathrm{~m}$ and $2 \mathrm{~m}$. The zero mark is the location of the emitter and receiver instruments. The $2 \mathrm{~m}$ peak is the acoustic response of the core.

As resonance peaks can be difficult to identify, due to all kinds of disturbance as well as the appearance of overtones generated on the basis of the 'real' resonance frequencies, it is necessary to make their detection more sensitive. Boumda, using the facilities of the Faculty of Engineering at the University of Bristol, developed a sensitive and precise measuring method and applied it to two flint blades. The experimental setup relies on applying acoustic excitation to a given part of the flint blade and measuring the response at different points using a Laser Doppler Vibrometer (LDV). This method was employed to measure the flint blade's displacement when it vibrates under excitation. The basic principle of an LDV is that it detects the Doppler frequency shift resulting from light being scattered by a moving surface. It is a non-contact measuring technique commonly used for lightweight structures [49]. The two flint blades tested are shown in Figure 5, and their dimensions are given in Table 1. Complex objects such as these are known to possess a multitude of resonance frequencies [50]. The first flint blade, labelled Sample 1, is curved but bears few flake scars on its dorsal surface. The second flint blade, labelled Sample 2, is relatively flat, but with numerous flake scars on its dorsal surface. 


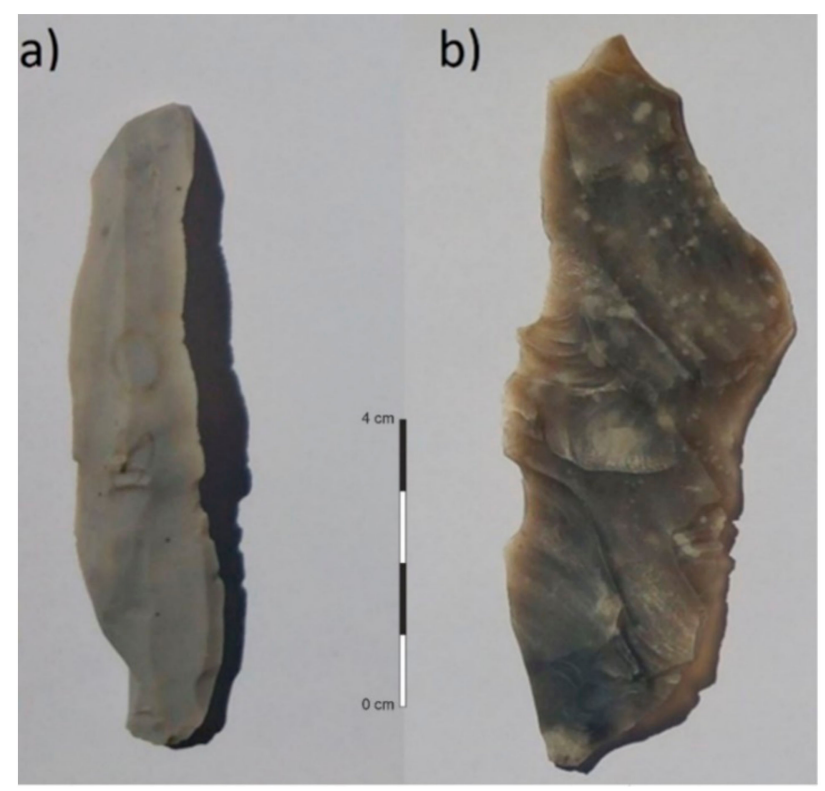

Figure 5. Flint blades used for the measurements. (a) Sample 1; (b) Sample 2. Photo \& graphic: Tayong Boumda.

Table 1. Dimensions and form of the flint blades tested.

\begin{tabular}{ccccc}
\hline & Length $(\mathbf{m m})$ & Width $(\mathbf{m m})$ & Thickness $(\mathbf{m m})$ & Curved? \\
\hline Sample 1 & 86.92 & 18.91 & 4.66 & Yes \\
\hline Sample 2 & 101.91 & 33.52 & 3.66 & No \\
\hline
\end{tabular}

The experimental setup used a compression driver SPLT5 as the acoustic source for excitation of the flint blades. The loudspeaker was placed directly behind the flint blade (about $5 \mathrm{~mm}$ away). A sweep frequency was selected as the generated wave function covering the frequency range of $100 \mathrm{~Hz}$ to $20 \mathrm{kHz}$. As the acoustic source generates sound waves, the flint is subjected to this excitation and will respond accordingly. At frequencies matching its natural resonance, the flint blade's distortion will increase sharply, and this is evident as peaks in the spectrum results. The latter were obtained by applying a Fast Fourier Function (FFT) to the time domain response. Throughout the entire measurement procedure, the speaker was subjected to a voltage of 2.5 volts to ensure that the flint blade distortion was sufficient for detection. A Faraday cage was also used to isolate the system from unwanted interference from the surrounding measurement devices. The LDV was placed about $510 \mathrm{~mm}$ in front of the flint blade, corresponding to the optimal stand-off for maximum visibility of the laser point. In order to optimise the signal-to-noise ratio, the smallest available velocity measurement of $20 \mathrm{~mm} / \mathrm{s}$ was selected and used throughout the procedure. A Butterworth third order high pass filter, with a cut-off frequency of $100 \mathrm{~Hz}$, was used to suppress low-frequency vibrations. The measurements were therefore carried out in the range of $(100 \mathrm{~Hz}-20 \mathrm{kHz})$ with 250 steps and using a sampling frequency of $500 \mathrm{kHz}$. The data acquired from the LDV were processed to display the frequency response by applying an FFT to the time domain results as stated above.

Figure 6 presents the magnitude and the phase as a function of frequency, obtained after measuring Sample 1 (top figures) and Sample 2 (bottom figures). The resonance frequencies (peaks) for Sample 1 are evident in Figure 6a: Below $20 \mathrm{kHz}$, there are five resonance frequencies, measured at 2.178, 6.494, 8.172, 12.25 and $19.92 \mathrm{kHz}$. The damping ratio was calculated using the $3-\mathrm{dB}$ technique applied to the fundamental frequency and found to be 0.0053 . The peaks are not equidistant and do not follow a regular pattern. This is primarily due to the complex shape of the flint blade, its curvature and possible internal heterogeneity. The phase for this flint blade was obtained using the Hilbert function and 
is shown in Figure $6 \mathrm{~b}$. There is $\pi$-change of the phase at the resonance frequencies. Both the magnitude and phase results should be used to detect resonance frequencies of the studied structure, as not all the peaks are due to the flint blade's vibrations. It is the $\pi$-change of the phase that confirms whether a peak is at a resonance frequency. Figure $6 \mathrm{c}$ depicts the magnitude result for Sample 2. In the range of frequencies measured, nine resonance frequencies were observed at 1.698, 3.936, 5.135, 7.932, 9.211, 11.85, 13.77, 16.56 and $19.12 \mathrm{kHz}$. This flint blade is relatively flat but is less homogenous than Sample 1. The damping ratio was also calculated for this blade and found to be 0.0088 . Figure $6 \mathrm{~d}$ corresponds to the phase for Sample 2. The new measuring method demonstrates that knapped flint pieces have lower resonance frequencies than those hitherto identified. This is interesting from a detection point of view as lower frequencies exhibit better penetration than higher ones and thereby permit detection of worked pieces deeper in the seafloor sediments.
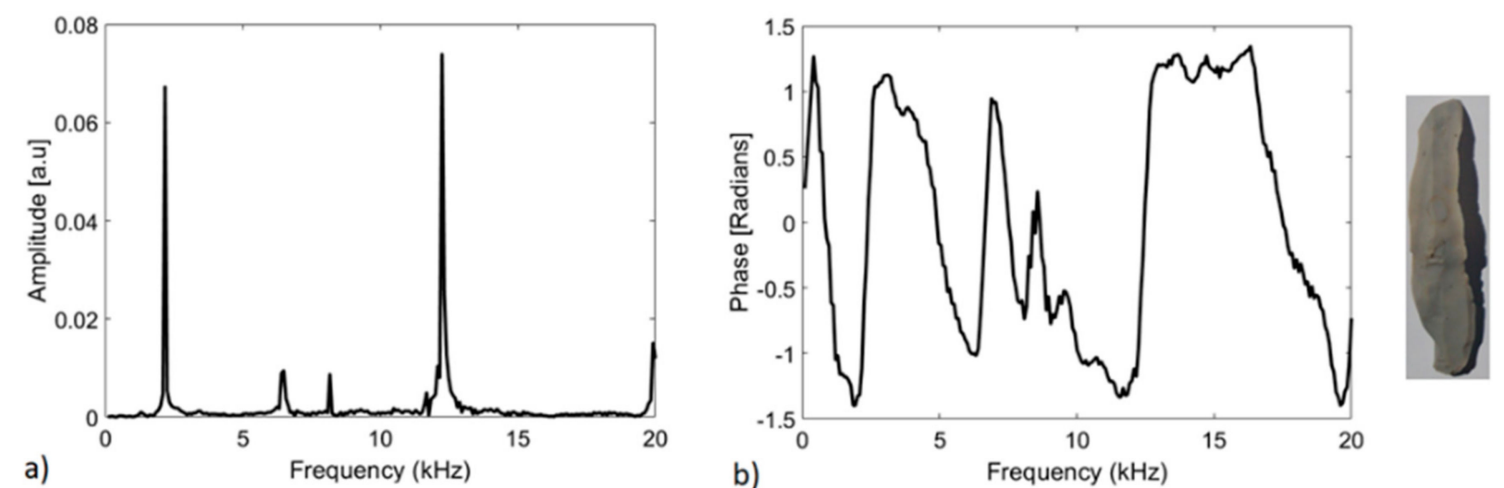

a)

b)

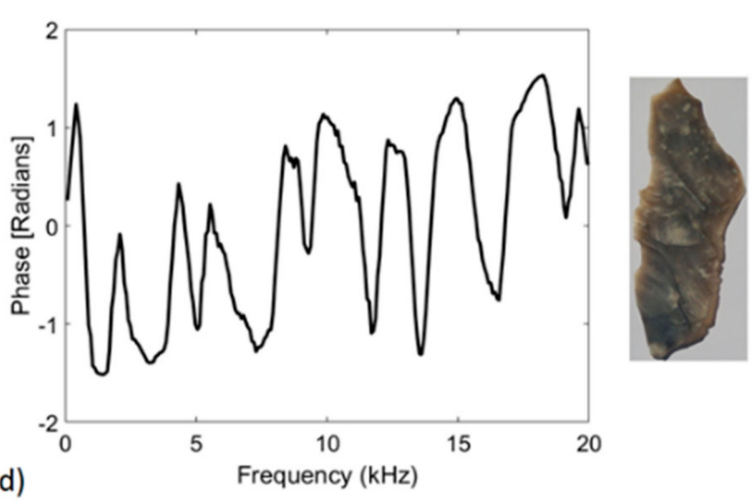

Figure 6. Spectrum results for the flint blades tested. (a) Magnitude for Sample 1; (b) Phase for Sample 1; (c) Magnitude for Sample 2; (d) Phase for Sample 2. Photo \& graphics: Tayong Boumda.

Finite Element (FE) modelling, undertaken by Hermand, Ren and Boumda, corroborated the Bang \& Olufsen and Wellbore Laboratory results, demonstrating that flint blades and flakes embedded in seafloor sediments do respond to the appropriate type of acoustic signal, and that they resonate at frequencies around $10 \mathrm{kHz}$ [51-53].

\subsection{Field Testing}

Experimental recordings on both knapped and naturally cracked flint pieces, were undertaken at sea using a Chirp III sub-bottom profiler (Teledyne, Thousand Oaks, CA, USA), which sweeps the frequency interval 2-20 kHz. Normally such an instrument is used for 'reflection seismics' - the recording of signal reflection from surfaces in the sediment. In this case it main function, however, is to record the resonance- - the acoustic responses-from human-knapped lithics it excites.

Before the test samples were placed on the seafloor in the Amager Lagoon, in the Sundby Harbour, and off Skovshoved, the test areas were covered with several sailing lines 
to secure the absence of disturbing acoustic features that could be mistaken for acoustic responses from knapped lithics. After the samples were placed on the seafloor clear acoustic responses were obtained from the positions where the knapped samples were placed but only from these positions, also when these pieces were embedded in sediment in plastic buckets. The naturally cracked pieces produced no detectable responses (Figure 7) $[41,54]$.

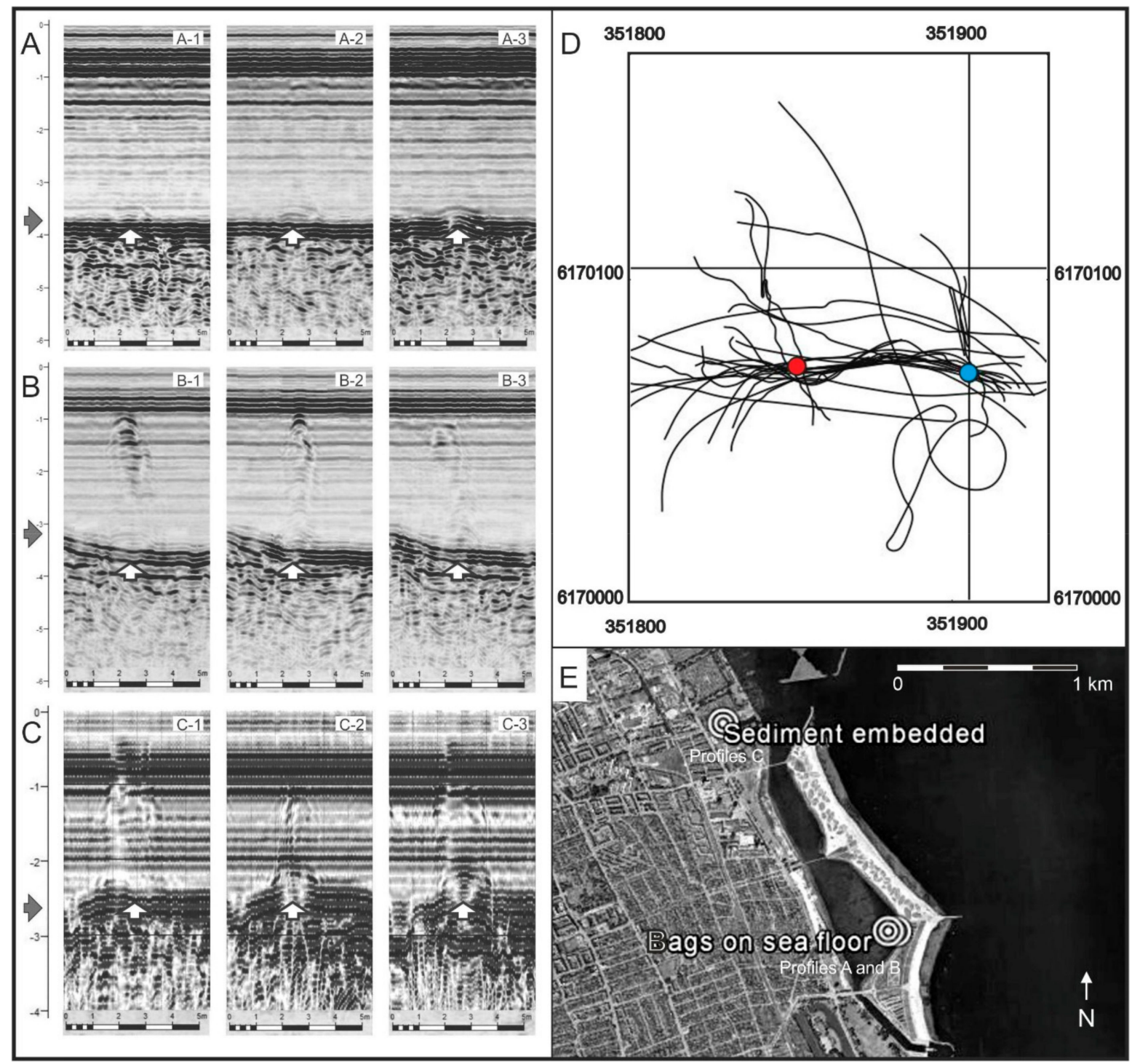

Figure 7. (A-C) Acoustic profiles recorded during resonance experiments. The grey arrows in panels (A-C) indicates the level of the seafloor. Cloth bags containing naturally cracked flint pieces (A), knapped flint pieces (B) and a bucket containing sand with embedded knapped flint pieces $(\mathbf{C})$ are marked with white arrows and can be discerned on the seafloor. (A1-A3) Experiment 1: $14 \mathrm{~kg}$ of naturally cracked flint in a cloth bag. No flint response is evident in the water column. (B1-B3) Experiment 2: $14 \mathrm{~kg}$ of knapped flint in a cloth bag. A clear acoustic flint response can be observed in the water column. (C1-C3) Experiment 3: $14 \mathrm{~kg}$ of knapped flint embedded in sediment in a plastic bucket. A clear acoustic flint response is evident in the water column. (D) The sailing lines for experiments 1 and 2. The blue dot marks the bag containing human-knapped flint debitage and the red dot marks naturally cracked flint. (E) Location of experiments in the southern part of the lagoon of Amager Strandpark, Denmark. Experiment 3 was located in Sundby Sailing Union's small harbour, north of the lagoon [41]. Zone 33 UTM coordinates. Graphic: Grøn.

Acoustic response features from knapped lithics generally distinguish themselves from gas bubbles in the water phase by not stretching all the way from the seafloor to the water surface. Opposite the mobile responses from fish or fish shoals the lithic 
response features are stabile over time with regard to position. That such features, repeating themselves at numerous passages of the test samples at three different test locations in shallow water $(2.0-7.5 \mathrm{~m})$ [41,54], should be the result of 'processing artefacts', too short recording windows, etc. is so unlikely that it can be excluded.

Until an optimized acoustic system for detection has been developed, off-the-shelf chirp subbottom profiling systems, which emit frequency intervals that cover the resonance frequencies measured for lithic flakes and blades, have been used for exciting and recording responses from human-knapped lithics in submerged prehistoric cultural layers. A Teledyne III Chirp, which sweeps the frequency interval 2-20 kHz, has been used for the recordings in Europe and Israel, whereas an EdgeTech 3100P (West Wareham, MA 02576, USA), covering the frequency interval 4-24 kHz, has been used in USA.

In Europe, different high precision DGPS systems in combination with different local calibration systems have been used to register the positions of the recorded features with sub meter precision. The processing and interpretation of the recorded data was carried out with different systems including free ware programs such as KOGEO and Petrel due to a Petrel University grant issued by Schlumberger to the Geology Group of the Department of Geosciences and Natural Resource Management at the University of Copenhagen. Recordings in the USA used a high-precision enhanced-fix GPS, employing wide area augmentation system (WAAS) with an accuracy of 1-2 $\mathrm{m}$. The data were mainly recorded and stored in SEG-Y format with Chesapeake's SonarWiz system (Los Altos, CA 94022, USA).

During field trials, the recording speed was kept between 1-2 kns relative to the sea floor to obtain a high horizontal resolution of the data [42]. When possible, field data were collected during calm conditions, which produces cleaner data. Power, gain, pulse length, etc. was varied during the recordings to optimize the data quality. This process was based on experience and ongoing experimentation with the parameter settings, in relation to variations in the seafloor sediments and the depth.

\section{Results of the Applications of the HALD Method to the Investigation of Submerged Stone Age Sites}

To test the implications of the results obtained experimentally and by FE modelling, acoustic detection has been applied to known submerged Stone Age sites off the Carmel Coast (Israel), in Lake Zürich (Switzerland) and in Roskilde Fjord (Denmark). Subsequently, it has been employed to survey areas for hitherto unknown submerged Stone Age sites in Florida (USA), and most recently in Kalmar (Sweden) and Svanemøllen Harbour (Denmark). This has resulted in the recording of a large number of acoustic anomalies in the water phase above known sites, indicating the presence of hitherto unknown Stone Age sites; several of these have now been verified. As it is quite demanding, given the present developmental stage of the technology, to detect or refute the presence of Stone Age sites potentially embedded several metres into seafloor sediments, the verifications undertaken to date are mainly from easily accessible sites with material exposed on the surface.

The first observations of an acoustic response from knapped lithics obtained on an experimental basis were at the Atlit Yam site in Israel, where huge noise features ('haystacks') were observed in the water phase above areas with cultural deposits and lithics (e.g., Figure 8). Continued work with the data from this and other sites shows that these haystacks appear to be concentrations of narrow columns of noise in the water phase similar to the acoustic responses obtained in the experiments (Figure 7B,C, Figure 14A-D and Figure 16A-C). In some cases, the acoustic responses from known Stone Age sites are solely evident as separate noise columns apparently representing the responses of small concentrations of knapped lithics (Figure 14A-D). Data recorded under optimal recording conditions at known sites in Lake Zürich with very low densities of knapped lithics underpin the assumption that the noise columns can represent the responses of individual pieces of knapped lithics (Figure 16A-C). 


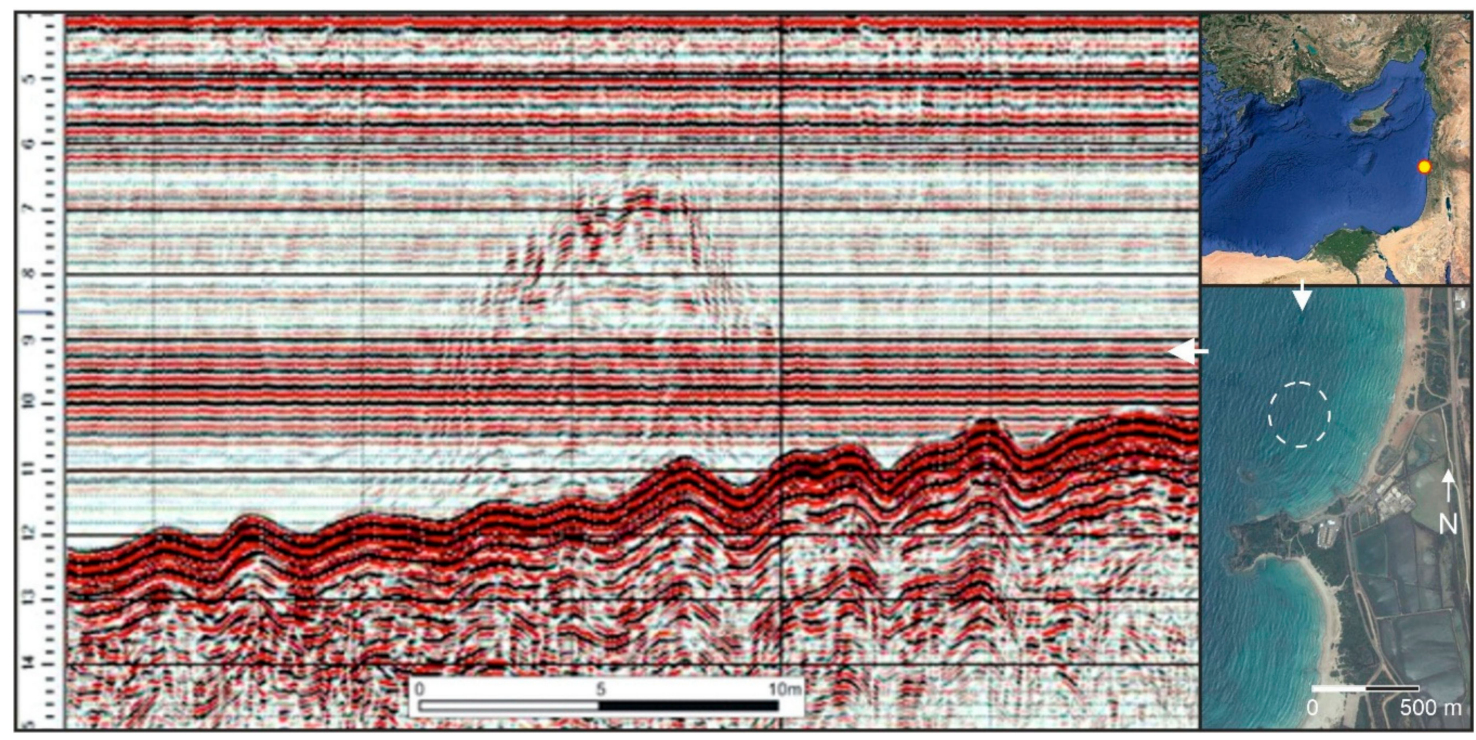

Figure 8. Left: A characteristic example of a haystack feature recorded at Atlit Yam. The seafloor is evident as a dark 'wavy' line below the haystack and the cultural layer as a dark horizon approximately $2 \mathrm{~m}$ below the seafloor. The depth is shown in metres to the left. Horizontal noise bands can be seen in the water phase. Right: location of Atlit Yam in the Mediterranean Sea (top) and off the Carmel Coast (bottom) Graphic: Grøn.

\subsection{Atlit Yam, Carmel Coast, Israel}

Atlit Yam is a Late Mesolithic and Early Neolithic site off the Carmel Coast (Israel), which has produced large quantities of knapped flint as well as having a number of preserved features such as graves, wells, wall foundations etc. It lies at a depth of 10-12 m [55]. It was the first known submerged Stone Age site to which this method was applied (in 2015). Within the surveyed part of the settlement, the recordings showed a strong correlation between the areas with knapped flint and preserved structures and the 'haystacks' (Figure 9) [41] observed in the water phase-a very specific noise-related phenomenon, apparently caused by the knapped lithics.
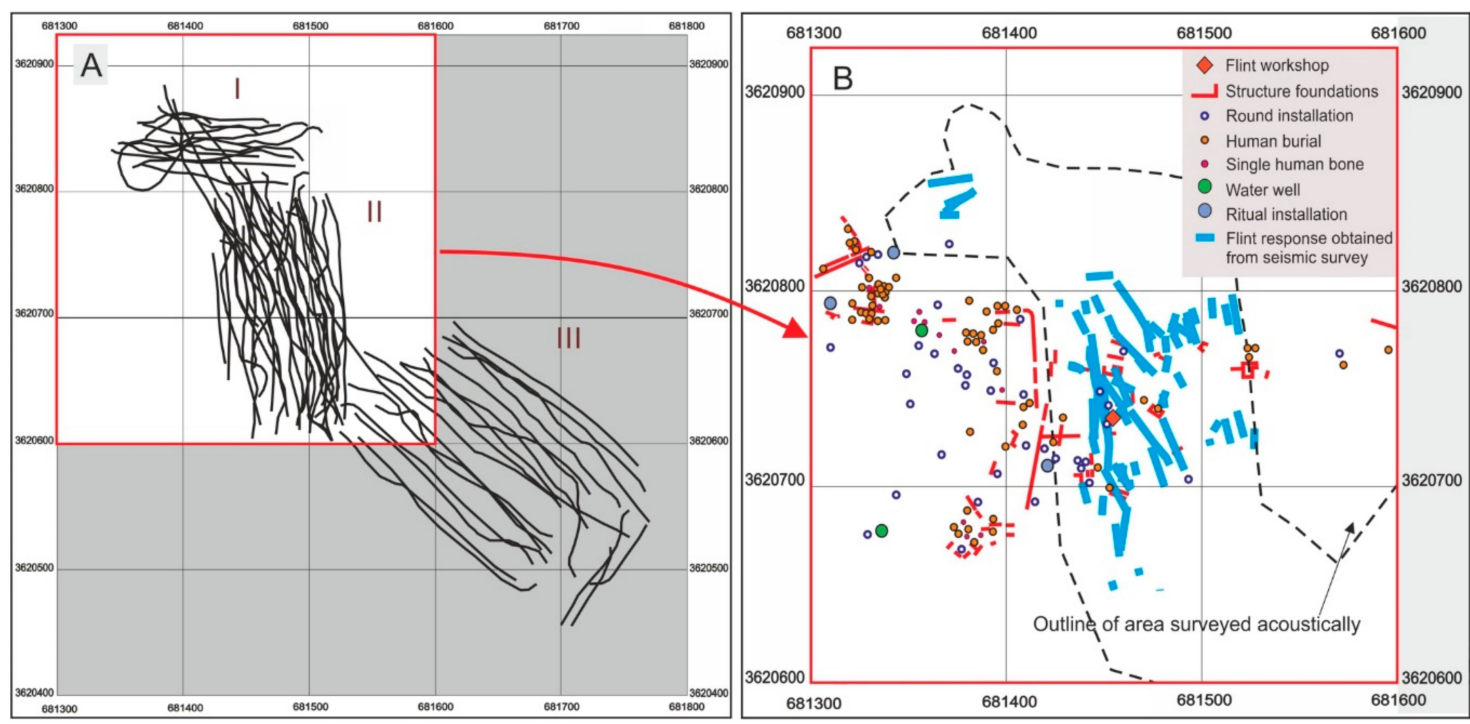

Figure 9. (A): The survey lines recorded at Atlit Yam. (B): The surveyed part of the settlement area is marked with the dashed black line. In the upper right corner is a key to the different types of settlement features recorded through excavation within the settlement area. The blue lines mark locations where haystacks were observed in the Chirp III profiles. Coordinates are in Universal Transverse Mercator (UTM, zone 36N). Settlement features are based on Galili \& Rosen (2011) and the original chirp-III recordings from 2014 [41]. Graphics: Grøn. 
An important aspect of these findings is that acoustic responses that were positionally stable over time were obtained from areas where the cultural deposits were covered by up to $2 \mathrm{~m}$ of medium-sized sand (Figure 9). This supports the conclusion that knapped lithics can respond acoustically even when embedded in-and damped by-sediment [41].

\subsection{Møllegabet, Ærø, Denmark}

Møllegabet was the first systematically excavated submerged Stone Age site in Europe. The first part of the site, Møllegabet I, investigated from 1976 onwards, comprised a Late Mesolithic shell midden found at a depth of 1.5-2 m. Later, from 1993-1998, a boat grave and a well-preserved Early Ertebølle dwelling were excavated in a deeper, earlier part of the settlement, Møllegabet II [56].

During a seismic (chirp) survey undertaken by Grøn in 1996, a number of profiles were recorded at the Møllegabet site [56]. One reason for doing this was to test the idea that the chirp could excite an acoustic response from the site's large quantity of knapped flint. As the dwelling area and the boat grave had by then been excavated in total, and most of the knapped lithic material had therefore been removed, the shell midden, of which only minor parts had been excavated, was chosen as the main target for this exercise. Two zones then yielded such strong, significant and clear acoustic responses (Figure 10) that these were interpreted at that time as being due to a technical problem or noise created by the shells in the midden. Only following recognition of the haystacks at Atlit Yam (Figure 8) and the experimental work undertaken off Amager (Figure 7), nearly 20 years later, were they identified as being due to acoustic resonance from knapped lithics, which were known to be abundant in the excavated parts of the same shell midden.

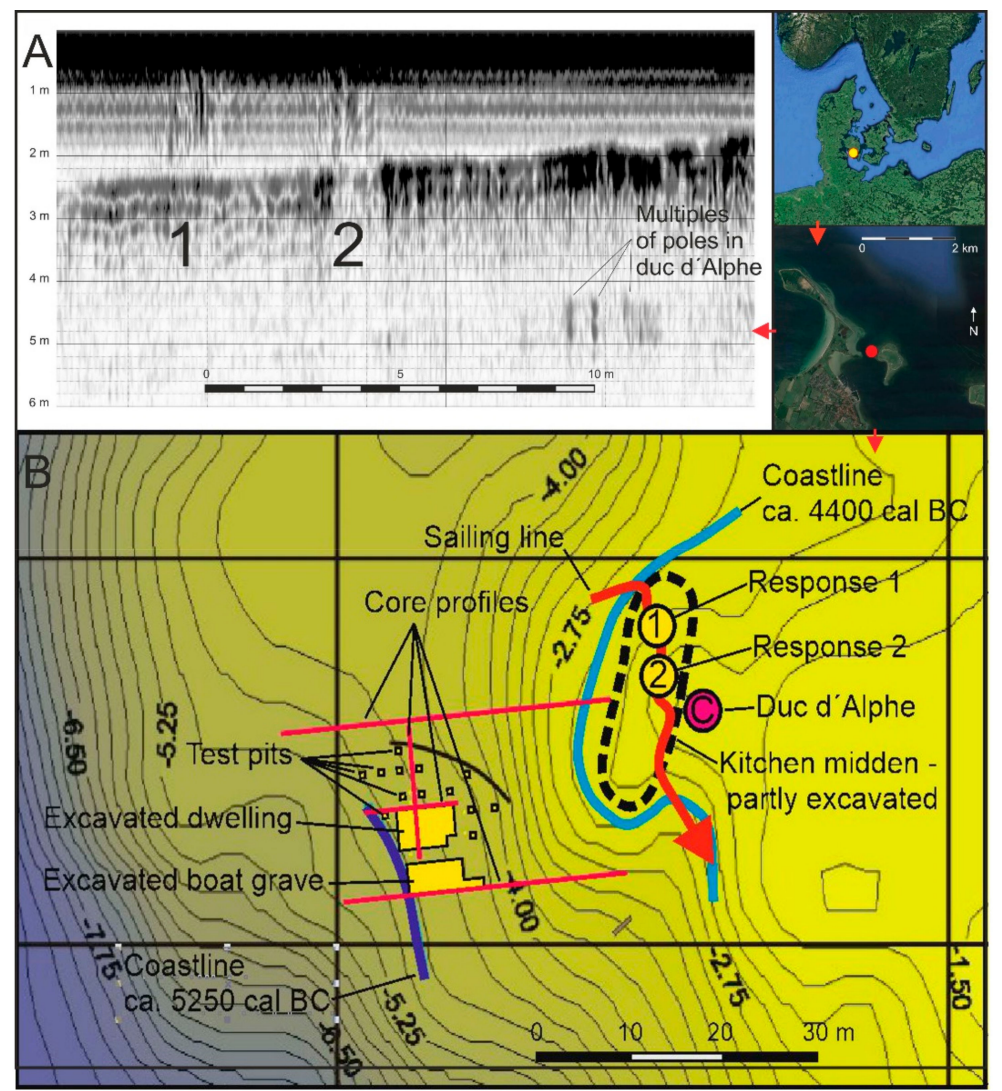

Figure 10. Recordings from 1996 of the submerged Stone Age settlement Møllegabet, Denmark, with a Datasonics Chirp II system, the predecessor of the Teledyne Chirp III. (A): Section cutting N-S through the kitchen midden at Møllegabet with two haystack features, 1 and 2. (B): A Bathymetric plan over the excavated Late Mesolithic archaeological features and the coastlines they date. The sailing line of A is shown in B as a bold, red arrow. Graphic: Grøn. 


\subsection{Florida, United States of America}

In recent years, Smith and Joy have used chirp survey to map a series of acoustic responses at Clints Scallop Hole (Apalachee Bay, Florida, 11 locations), as well as in inland waters such as Gilchrist Blue Spring (two locations), Lewis-McQuinn (one location) in the Suwannee River, and Mammoth Graveyard (one location) in the Silver River (Figure 11). Of these, Lewis McQuinn (one location), Glichrist Blue (two locations), Mammoth Graveyard (one location) and four of the Clints Scallop Hole locations have so far been diver-verified (Figure 12).

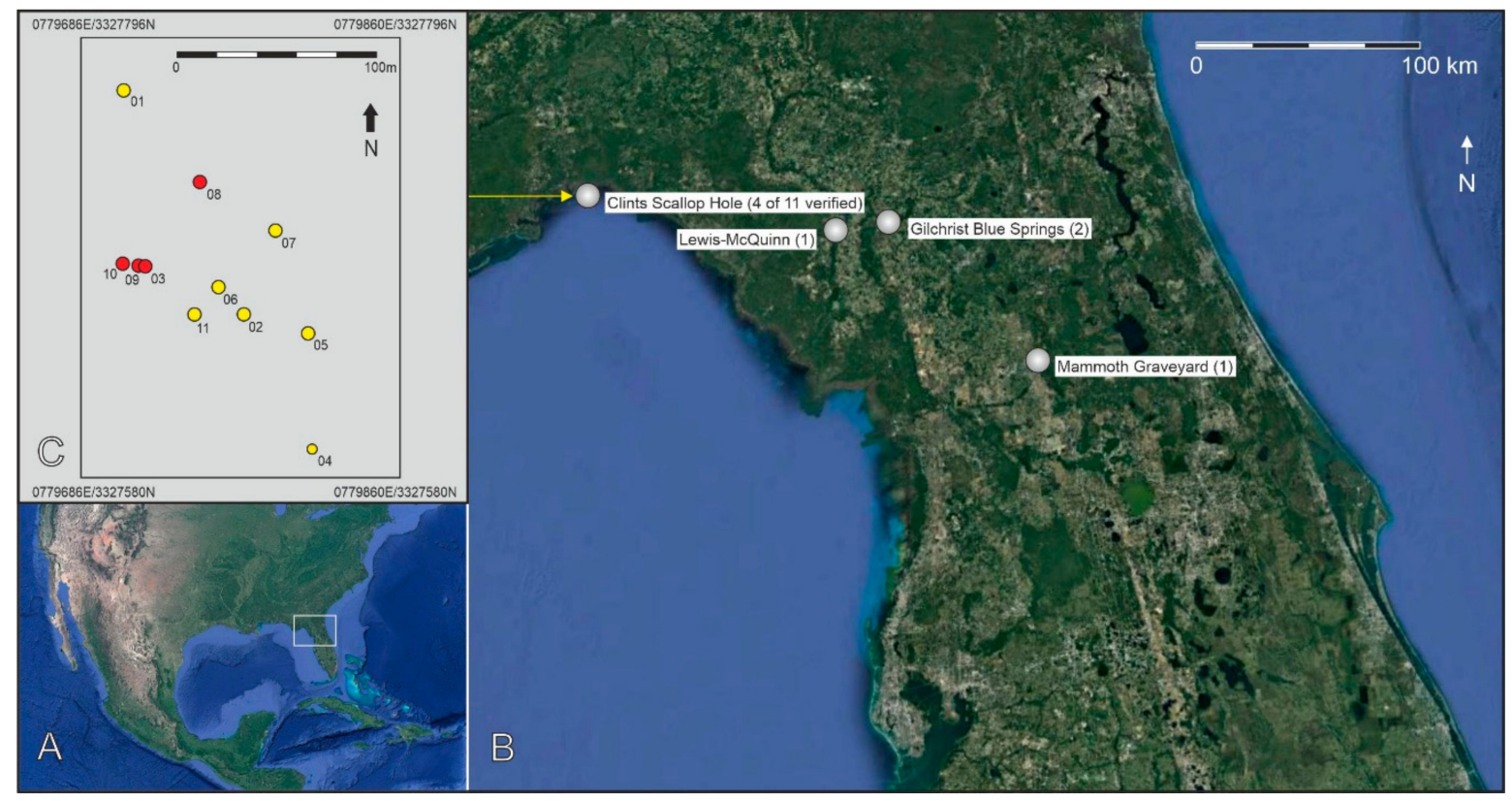

Figure 11. The sites in Florida, USA detected or tested by Smith and Joy. (A): overview. (B): Positions of the 15 sites (C): Detailed positions of the detected anomalies (yellow) and verified sites (red) at Clints Scallop Hole. Zone 17R UTM coordinates. Graphics: Grøn.

At Clints Scallop Hole, the seafloor comprises an extensive inundated landscape with numerous lithic scatters associated with bedrock chert outcrops, several of which have been extensively quarried. The sites lie at a depth of c. $2 \mathrm{~m}$ and they were inundated about 3500 calBP (1550 calBC) [57]. Some features preserved at the site appear to be discrete knapping stations, as some lithics from the same station can be refitted. The chert present has been provisionally typed to the Wacissa Cluster of Suwannee-type chert, which is a microspherulitic chalcedony [58]. Eleven acoustic targets were recorded during the 2018 survey. Four of the 11 targets have been diver verified thus far. Marker buoys were placed at the acoustic target locations and divers descended the buoy downlines. Previously unrecorded lithic scatters were identified at all four targets, in less than $5 \mathrm{~min}$ and within $10 \mathrm{~m}$ of the buoy. The lithic scatters were both on the surface and buried $15 \mathrm{~cm}$ under medium sand. The number of artifacts at each location is estimated at 100-200 lithics.

At Gilchrist Blue Spring, which feeds into the Santa Fe River, a haystack feature was observed over a surface lithic scatter of chert previously recorded in the spring run. A further scatter was detected with the chirp and accordingly verified. Based on the preservation of organic material in the stratigraphy of the spring run, it appears that the Gilchrist Blue was inundated due to a rise in groundwater level during the Late Pleistocene [59].

Haystack signatures were used to locate a previously unrecorded underwater site in the Silver River, near the Guest Mammoth site. Divers were deployed to a precise location marked by a haystack feature and found a knapped chert shatter where no archaeological material had previously been recorded (now named the Mammoth Graveyard site). Based 
on the preservation of organic material, it appears that this portion of the Silver River was inundated about 7000 calBP (5050 calBC) [60].

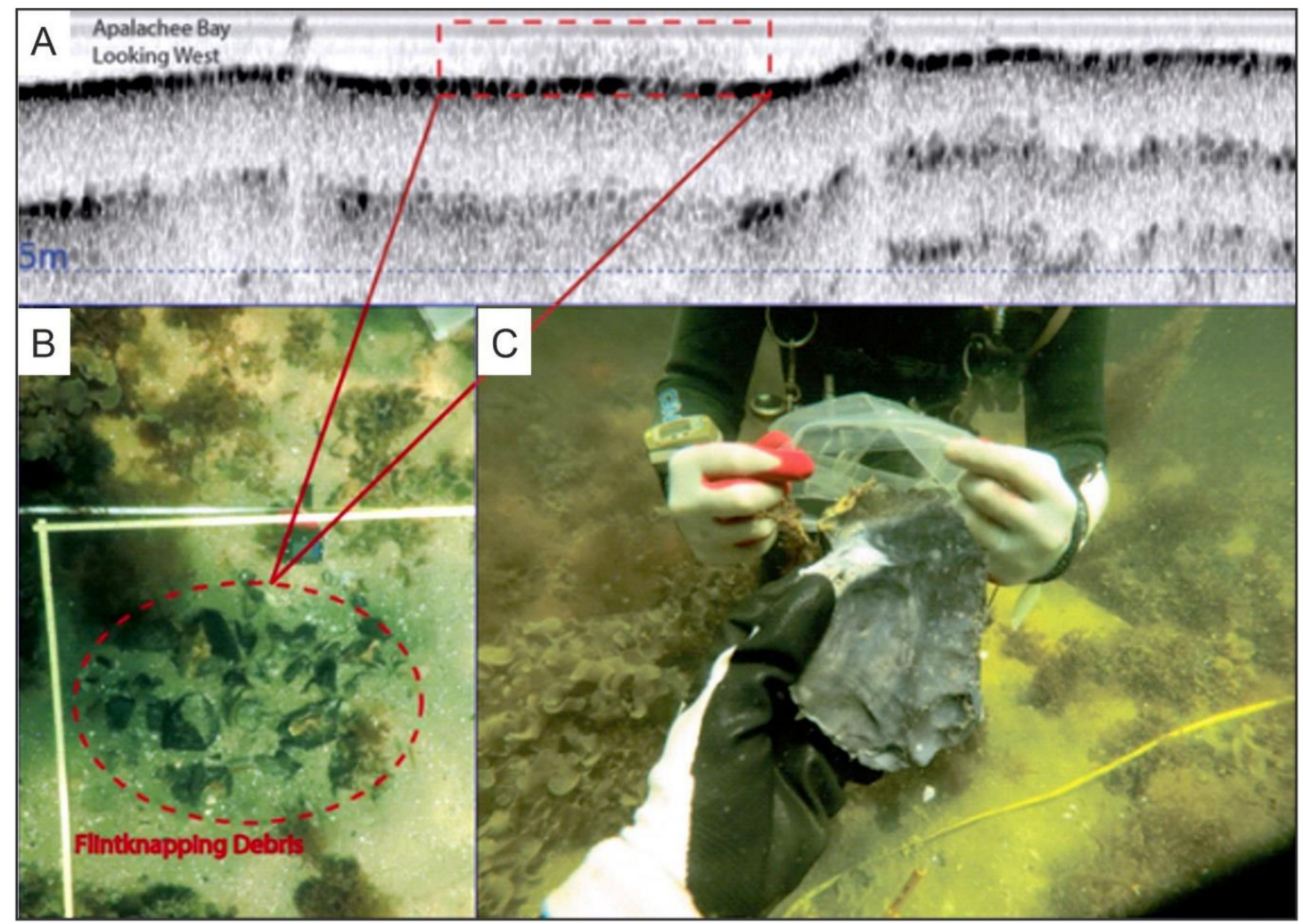

Figure 12. Images from archaeological work at the Clint's Scallop Hole site 8je1796 in 2019. (A): Segment of the sub-bottom profile of the site showing a haystack feature over the site. Coral heads are present in the area visible as solid 'peaks' in the water phase. (B): An in-situ flintknapping station preserved at the site. (C): A bifacial preform recovered by divers at the site. The slight difference in the appearance of the haystacks from Clint's Scallop Hole, versus those identified in Europe by O. Grøn and colleagues, is likely a result of different SONAR acquisition systems. At Clint's Scallop Hole, an EdgeTech 3100P was used to obtain data. Photos: Joy \& Smith.

On the Suwannee River, a haystack feature at the Lewis-McQuinn site was detected. Diver-verification and subsequent excavation documented lithic artefacts on the spot. The freshwater sites and their associated acoustic response features demonstrate that sites can be detected following freshwater inundation.

\subsection{Roskilde Fjord, Denmark}

In 2020, Boldreel undertook chirp recordings at three already known and precisely positioned Late Mesolithic sites in Roskilde Fjord (Figure 13). All of these produced observable acoustic responses (Figure 14A-D). Site 1, the 'Blak' site (401257-3), is a 1.5-4 m-deep settlement of the Kongemose culture, a part of which was investigated intensively by S. Sørensen in 1989-93, based on a $100 \times 100 \mathrm{~m}$ recording area [61,62]. His work included recording of preserved cultural deposits in four areas within and outside the recording area (Figure 13B). Two excavations were carried out inside the recording area. At the northern Blak I site, approximately $10 \mathrm{~m}^{2}$ of material from the late Villingebæk phase of the Kongemose culture at a depth of 1.5-2 m was excavated and dated to 8130-7640 calBP (6180-5690 calBC). At the southern type site for the early Blak phase of the Kongemose culture, Blak II, at a depth of 3.4-3.9 m, an area of $137 \mathrm{~m}^{2}$ was excavated and remains dated to approximately 8370-8150/8050 calBP (6420-6200/6100 calBC). The excavations produced a moderate amount of lithic material with a representative typological variability, concentrations of dumped burnt stones and some bone artefacts, as well as a bone assem- 
blage reflecting marine fishing and terrestrial hunting, which was associated with remains of heavily charcoal-stained cultural deposits. A detailed geological investigation, including the analysis of a several cores, was carried out by Roskilde University on the site during the 1990 excavation campaign [61-63].

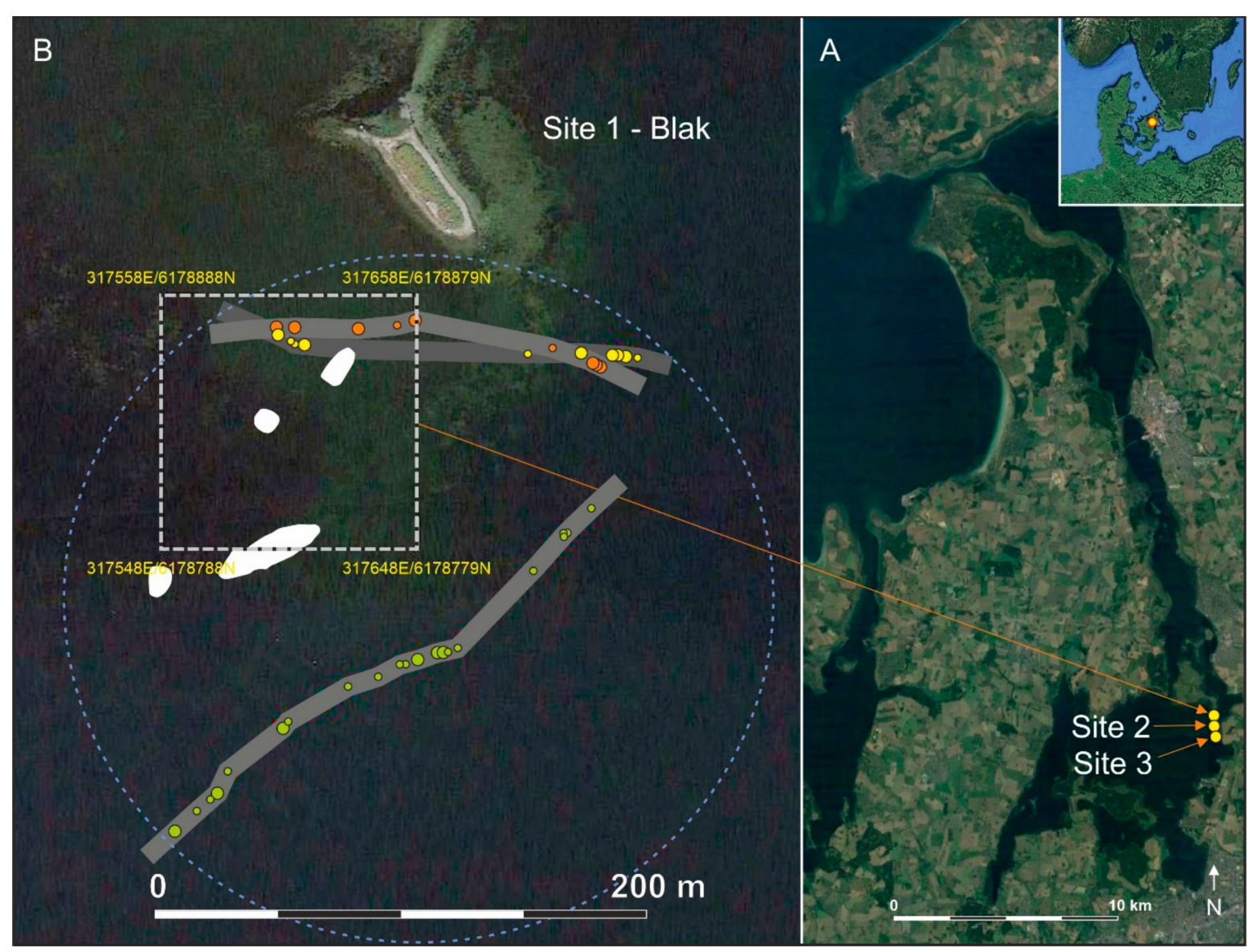

Figure 13. (A): The three already recorded Late Mesolithic sites in Roskilde Fjord, site 1 (401257-3), site 2 (401257-56), and site 3 (401257-57), selected for testing of acoustic response. (B): Especially site 1, the 'Blak' site, is interesting because it is well-documented by intensive investigations, including an excavation based on a $100 \times 100 \mathrm{~m}$ recording area (white broken square). Preserved cultural deposits (white patches) and numerous cultural indicators were recorded inside and around the recording area. Each of the three sailing lines, and their recorded noise columns, are shown with an individual grey shade and a specific dot colour. The size of the dots is equivalent to their estimated significance. The estimated outline of the site is marked with as a broken blue circle. Zone 33 UTM coordinates. Graphics: Grøn.

Site 1 clearly extends outside the recording area. The concentration of rather strong and narrow noise columns to the east of the site (Figures 13A and 14A) are from a zone where the bottom consists of soft mud and which so far has produced no finds (Sørensen, Museum Lolland-Falster, Nykøbing Falster, Denmark, personal communication, 2020). This may be due to the Mesolithic deposits here being covered by later sedimentation. The acoustic responses on the southern sailing line may represent continuation of the investigated site features to the south. The responses from the northern part of the recording area are less clear due to the shallower water depth here (Figures 13 and 14B). A suggested outline of the site is shown in Figure 13.

Site 2 (401257-56) produced a few narrow noise columns at its recorded coordinates, and a significant concentration of such responses was recorded $80 \mathrm{~m}$ to the north of this position (Figure 14C). It is assumed that it is an outlier of this site that has been recorded. Site 3 (401257-57) exhibited a strong noise column a few metres from its recorded position (Figure 14D). 


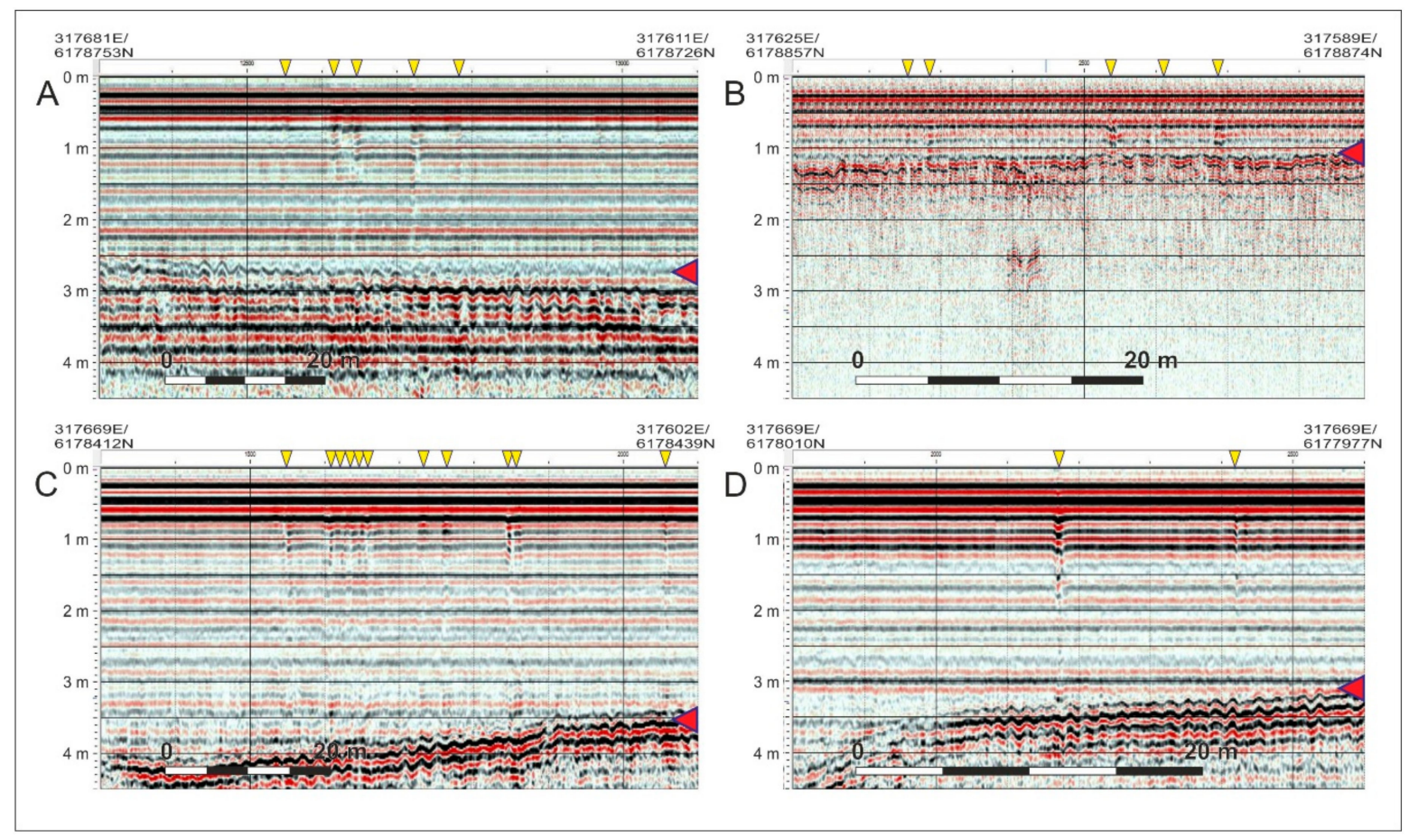

Figure 14. Profiles (A,B): acoustic responses from site 1, the Blak site (401257-3). Profile (C): acoustic responses from site 2 (401257-56). Profile (D): acoustic responses from site 3 (401257-57). The seafloor is marked with a red arrow at the right side of the profiles and acoustic responses with yellow arrows from above. Depth is shown at the left side. The horizontal scale of the profiles varies with the speed at which they were recorded. Zone 33 UTM coordinates. Graphics: Grøn.

\subsection{Meilen Schellen in Lake Zürich, Switzerland}

An experimental survey in Lake Zürich of several known Bronze Age and Neolithic pile dwelling sites, most of which have been partly excavated (undertaken by Grøn and Boldreel in 2019 for Unterwasserarchäologie/Dendrochronologie Zürich under Amt für Stadtebau Zürich), resulted in the recording of numerous very narrow noise columns in the water phase in the settlement areas. As the amount of knapped lithic pieces at such sites is normally quite low in this area, it appeared during the interpretation that the narrow columns might represent acoustic responses from single lithic pieces. Data from the site of Meilen Schellen have been used here to investigate this possibility further (Figure 15).

The Meilen Schellen site has attracted the attention of both amateur and professional archaeologists since the 1930s. What started as rather unsupervised artefact recovery has been replaced by professional excavation [64]. The major 1975-77 excavation of $430 \mathrm{~m}^{2}$ up to $1.2 \mathrm{~m}$ thick cultural deposits, dominated by Neolithic material (Cortaillod and Pfyn cultures), is of special interest, due to its extent and to the information it provides about the low density of knapped lithics. Although they were only excavated to a depth that would facilitate the dredging of a deeper passage for boats to the shore, the recorded sections suggest that the cultural deposits were excavated more or less to their bottom [64].

The $430 \mathrm{~m}^{2}$ excavation undertaken in 1975-77 yielded 293 pieces of knapped lithics/ artefacts. The lithic material employed in prehistory ranged from a dominant fraction of local radiolarite and quartzite of lesser knapping quality to a variety of more exotic materials. Regular flint was practically absent [64:87-108]. The average lithics density in the parts of the cultural deposits surrounding this excavated area can therefore be estimated as around $0.5-1$ pieces per $\mathrm{m}^{2}$. As the water depth around the area excavated in 1975-77 is $2-2.5 \mathrm{~m}$ and the angle of the chirp signal is approximately $20^{\circ}$, the 'footprint' - i.e., the area affected by the emitted pulses-will be on average about $80 \mathrm{~cm}$ in diameter. The recordings will therefore cover a $80 \mathrm{~cm}$-wide band, with an expected 'linear density' of around $0.4-0.8$ pieces per metre. This figure may actually be a bit higher in the unexcavated parts of the cultural deposits, because some of the smaller items will tend to have been 
overlooked during such a complicated excavation process, and because the three profiles which were selected due to their quality are in the part of the excavation with the obviously deepest cultural deposits [64:18-28].

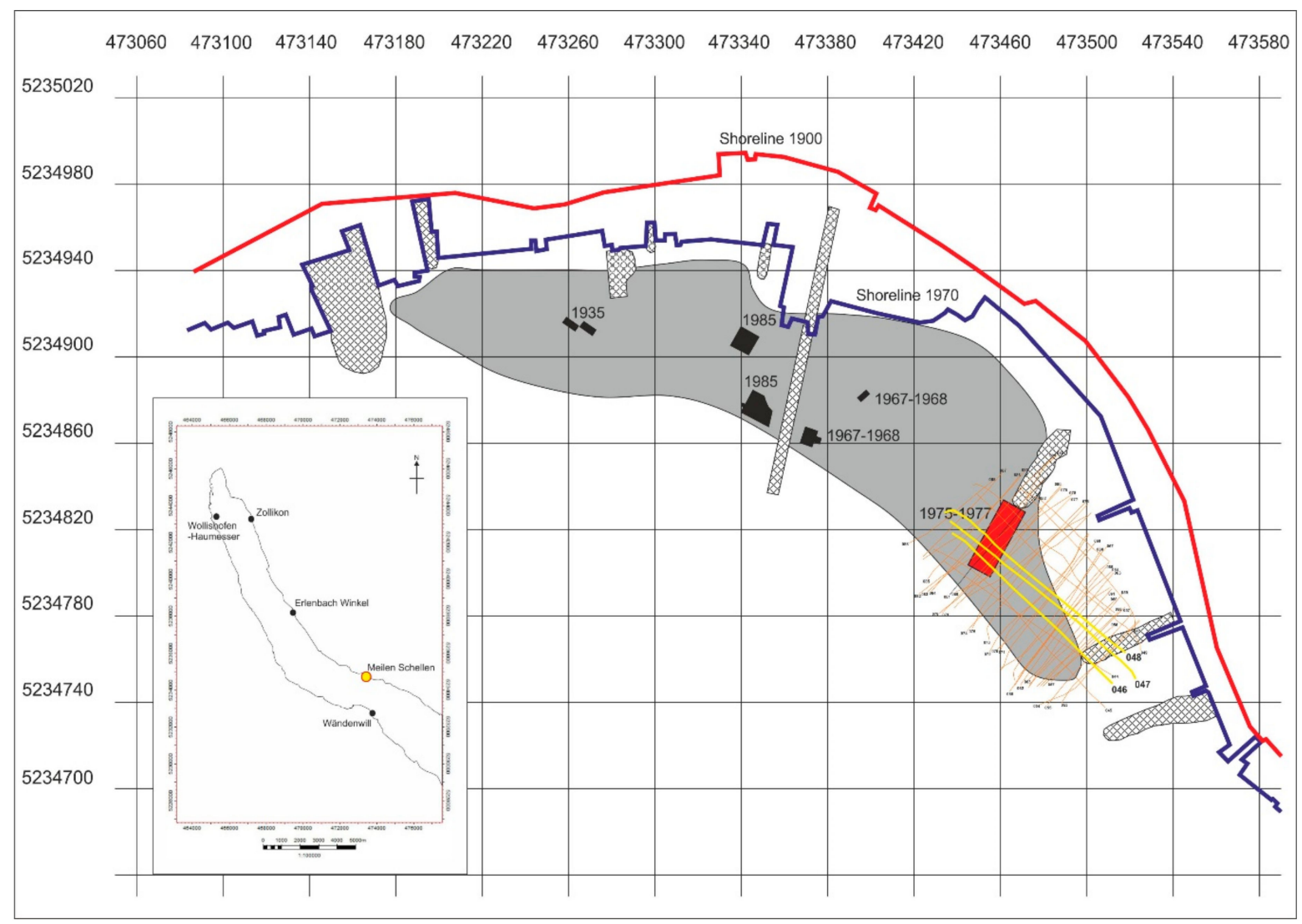

Figure 15. Meilen Schellen with its up to several metre-thick cultural deposits (grey area) comprising both Neolithic and Bronze Age horizons. The excavations are marked as black areas, apart from the 1975-1977 excavation in focus here, shown in red, where the cultural deposits are $1.2 \mathrm{~m}$ thick. Disturbances that have facilitated archaeological/stratigraphic observations through time are crosshatched. The sailing lines from 2019 are orange, with the lines 46-48 in yellow. UTM zone 32T coordinates. Based on Altorfer \& Conscience 2005: 11-15. Graphic: Grøn.

The three profiles 46-48, which cut through the $16 \mathrm{~m}$ wide excavation area, have been analysed. Counting of the number of small narrow 'noise columns' which could be distinguished in the unexcavated $20 \mathrm{~m}$ to the east of the excavation area gave a total of 53 distinguishable columns (Figure 16A-C), equivalent to 0.88 lithic pieces per metre. This figure is of a reasonable order of magnitude and thereby supports the conclusion that responses from individual lithic pieces can be distinguished under good recording conditions.

Compared with a profile (Figure 16D) with no noise features in the water phase from the same lake which has its 'top noise' intact, i.e., the horizontal band that always features in such recordings slightly below the surface in the water phase (e.g., Figures 8 and 14), it is interesting to see how the Meilen Schellen profiles featuring numerous acoustic responses show disturbance of their 'top noise' band (Figure 16A-C). 


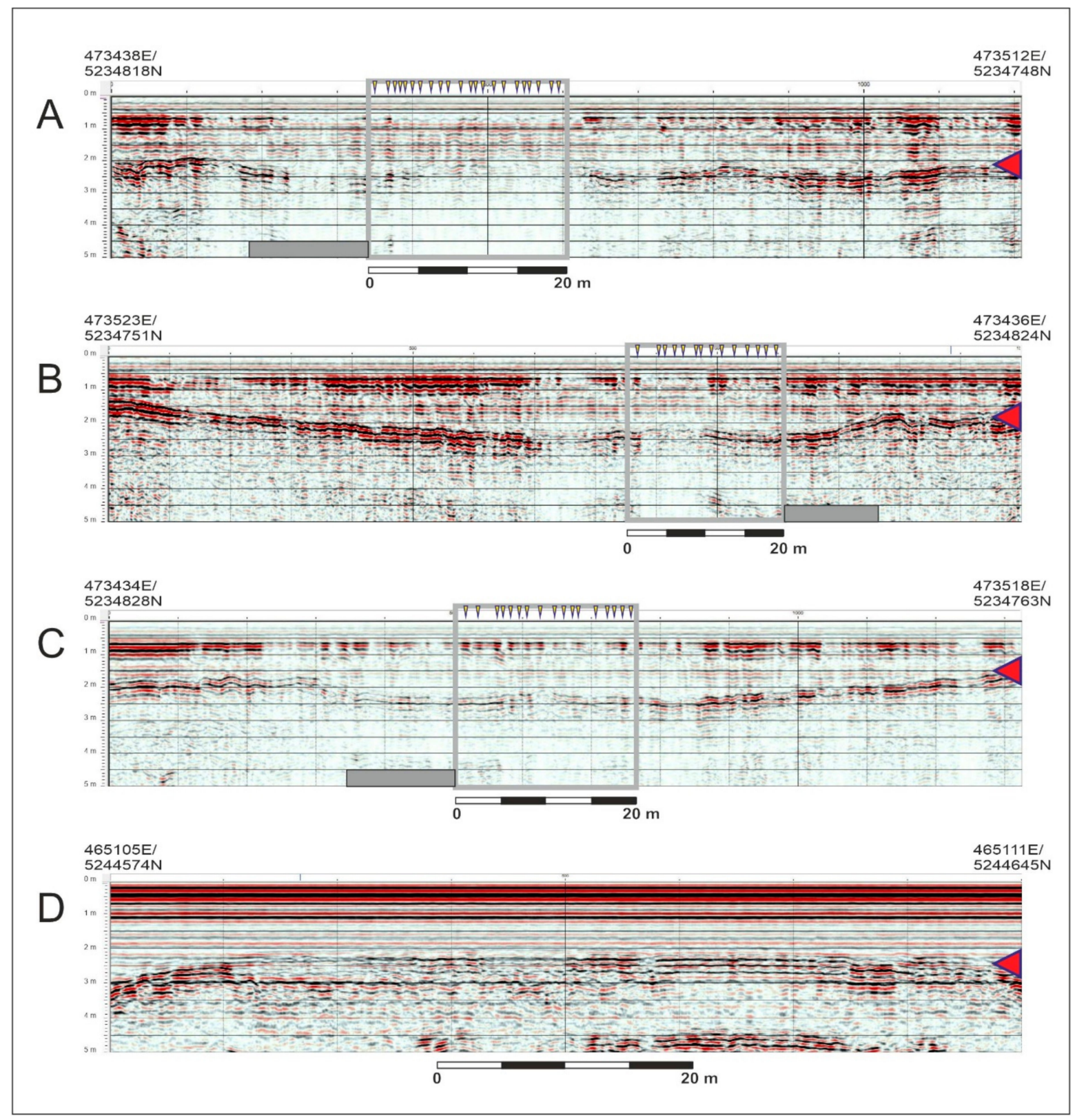

Figure 16. (A-C): Profiles through the 1975-1977 excavation area marked as a grey bar. The narrow noise columns 0-20 $\mathrm{m}$ east of the excavation area (grey square) are marked with yellow arrows from above. (D): Reference profile from Lake Zürich with no noise columns in the water phase but with its horizontal band of 'top noise' undisturbed. The seafloor is marked with a red arrow at the right side. The horizontal scale of the profiles varies with the speed at which they were recorded. Zone 33 UTM coordinates. Graphics: Grøn.

\section{Discussion}

The development of HALD, a new, cost-effective acoustic approach for the rapid identification and mapping submerged Stone Age sites presented in this paper, is based on two interacting elements: (A) application of the method in experimental fieldwork and (B) experimental laboratory work including FE-modelling. The aim of this development strategy is to reduce the weight of both constituent elements through a synergetic interaction between them. For example, the development of an explanatory model for the acoustic phenomenon observed and utilised in this project helps focus the experimental fieldwork and make it more efficient. The work has so far demonstrated the method's convincing ability to detect submerged sites in practice, regardless of whether their lithic 
material is exposed on the seafloor or embedded several metres into its sediments (Table 2). The recordings from Meilen Schellen (Figure 16A-C) and Atlit Yam (Figure 8) indicate that, under good recording conditions, the present system is able to produce observable responses from both individual pieces embedded more than a metre into the sediments, and from a certain density of pieces embedded in cultural deposits several metres into the seafloor. The recent identification of resonance frequencies for blades as low as $2 \mathrm{kHz}$ is a promising development, as this should permit detection of knapped lithics located deeper in the sediments than hitherto anticipated.

The wide variety of knapped materials, in addition to flint, which gave responses shows that the method has a broad application range and appears to work regardless of raw material type (Table 2). An important observation in relation to this aspect is that the silicate content is a primary factor relative to a lithic materials' suitability for knapping [65]. The volcanic tuff from the Siljan area of Sweden, which was knapped in the Stone Age, is for example not the typical light tuff that was popular for building works during the Medieval period. It is saturated with silicates from the Siljan meteor impact and this high silicate content has made it well-suited to knapping [66,67]. From a flint-knapping point of view, the multi-facetted geological terms for the various types of knapped material, i.e., flint, obsidian, quartzite, volcanic tuff, mudstone/shale, Jurassic hornstone, bean jasper etc., can be reduced to an assessment of the homogeneity and silicate content of the various materials, and thereby their suitability for knapping. This simplifies the situation greatly, as the variation in the basic material constants that must be accounted for in our experiments and development work can therefore be reasonably assumed to be much less than if we had to deal with quite different standards for volcanic tuff, mudstone/shale, obsidian etc. The production of a number of 'standard samples' of the various lithic materials used for knapping in prehistory is currently ongoing, thereby experimentally underpinning this aspect, and consequently simplifying the production of an optimal detection strategy.

Fieldwork undertaken in Lake Zürich (Canton of Zürich, Switzerland), Svanemøllen Harbour (Copenhagen, Denmark), Roskilde Fjord (Denmark), and Eriksberg (Kalmar, Sweden), indicates that narrow noise columns ('bundles') visible in the water phase may reflect the acoustic responses from one or a few knapped lithic pieces in a small concentration (Figure 16A-C). Where the recorded data are of a good quality the often quite large and broad haystacks seem to be composed of these narrow bundles, which also appear more dispersed, probably depending on the concentration of lithic material (Figure 10A, Figure 14A-D and Figure 18A,B). Fieldwork undertaken in Florida (USA), demonstrates that haystacks are not constrained to a certain chirp sub-bottom instrument type or lithic material. Smith and Joy have also used haystacks to identify previously unrecorded sites, in both fresh and saltwater, which they have confirmed as containing lithic material by diving.

The general experience shows that the acoustic responses from knapped lithics embedded in the seafloor sediment appears not to be affected by the sediment type. Apparently, all water saturated sediments as well as cultural deposits provide good acoustic signal penetration.

A survey undertaken by Boldreel and Grøn in autumn 2020 at Svanemøllen Harbour (Copenhagen, Denmark) exhibited a significant concentration of non-mobile (i.e., not fish shoals) haystacks and noise columns related to a prehistoric landscape at a depth of 7.5-9 m, consisting of little islands and peninsulas slightly capped by recent dredging. This landscape is covered by $1 \mathrm{~m}$ of silt which is difficult to distinguish in the recordings due to its water-like acoustic properties. The perimeter of this acoustic anomaly encloses an area of approximately $80 \times 120 \mathrm{~m}$ and it appears to have a central area of $30 \times 40 \mathrm{~m}$ large with a quite high density of response features. Based on the present results, it is difficult to interpret this unverified feature as anything other than a significant Stone Age site which, due to its depth, must belong to the Early Mesolithic Maglemose culture (Figure 17). 
Table 2. Summary of key attributes of sites mentioned in text which have been subjected to HALD testing.

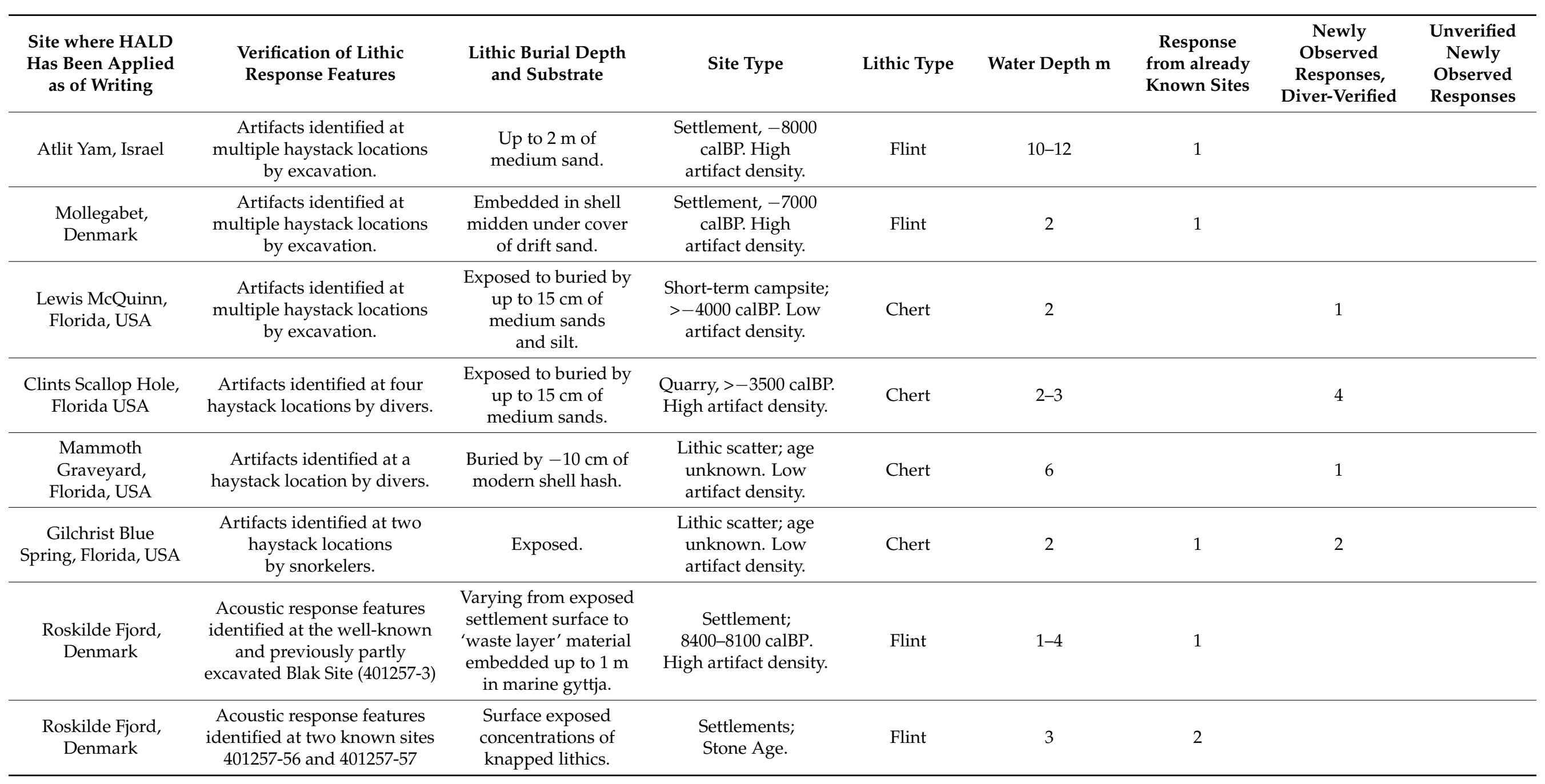


Table 2. Cont

\begin{tabular}{|c|c|c|c|c|c|c|c|c|}
\hline $\begin{array}{l}\text { Site where HALD } \\
\text { Has Been Applied } \\
\text { as of Writing }\end{array}$ & $\begin{array}{l}\text { Verification of Lithic } \\
\text { Response Features }\end{array}$ & $\begin{array}{l}\text { Lithic Burial Depth } \\
\text { and Substrate }\end{array}$ & Site Type & Lithic Type & Water Depth m & $\begin{array}{l}\text { Response } \\
\text { from already } \\
\text { Known Sites }\end{array}$ & $\begin{array}{c}\text { Newly } \\
\text { Observed } \\
\text { Responses, } \\
\text { Diver-Verified }\end{array}$ & $\begin{array}{l}\text { Unverified } \\
\text { Newly } \\
\text { Observed } \\
\text { Responses }\end{array}$ \\
\hline $\begin{array}{l}\text { Meilen Schellen, } \\
\text { Switzerland }\end{array}$ & $\begin{array}{l}\text { Acoustic response features } \\
\text { identified at the location of } \\
\text { previously partly } \\
\text { excavated site. }\end{array}$ & $\begin{array}{l}\text { Embedded in up to } \\
-1.2 \mathrm{~m} \text { of cultural } \\
\text { deposits. }\end{array}$ & $\begin{array}{l}\text { Pile dwellings; } \\
\text {-5500 calBP. Low } \\
\text { artifact density. }\end{array}$ & $\begin{array}{l}\text { Local radiolarite, } \\
\text { quartzite, a } \\
\text { variety of more } \\
\text { exotic materials }\end{array}$ & 2 & 1 & & \\
\hline $\begin{array}{c}\text { Svanemollen } \\
\text { Harbour, Denmark }\end{array}$ & $\begin{array}{c}\text { A } 8 \times 120 \mathrm{~m} \text { large } \\
\text { concentration of unverified } \\
\text { acoustic response features } \\
\text { identified in a recognizable } \\
\text { submerged landscape. }\end{array}$ & $\begin{array}{l}\text { Embedded in } 1 \mathrm{~m} \\
\text { of silt. }\end{array}$ & $\begin{array}{l}\text { According to the } \\
\text { depth it must be } \\
\text { Early Mesolithic } \\
\quad \text { or earlier. }\end{array}$ & Unknown & 7 & & & 1 \\
\hline Eriksberg, Sweden & $\begin{array}{l}\text { A large number of unverified } \\
\text { acoustic response features } \\
\text { identified in an area where no } \\
\text { submerged sites have earlier } \\
\text { been recorded. }\end{array}$ & $\begin{array}{l}\text { Embedded in } 0-2 \mathrm{~m} \\
\text { of silt. }\end{array}$ & $\begin{array}{l}\text { According to the } \\
\text { depth it must be } \\
\text { Early Mesolithic } \\
\quad \text { or earlier. }\end{array}$ & Unknown & $1-6$ & & & Many \\
\hline
\end{tabular}




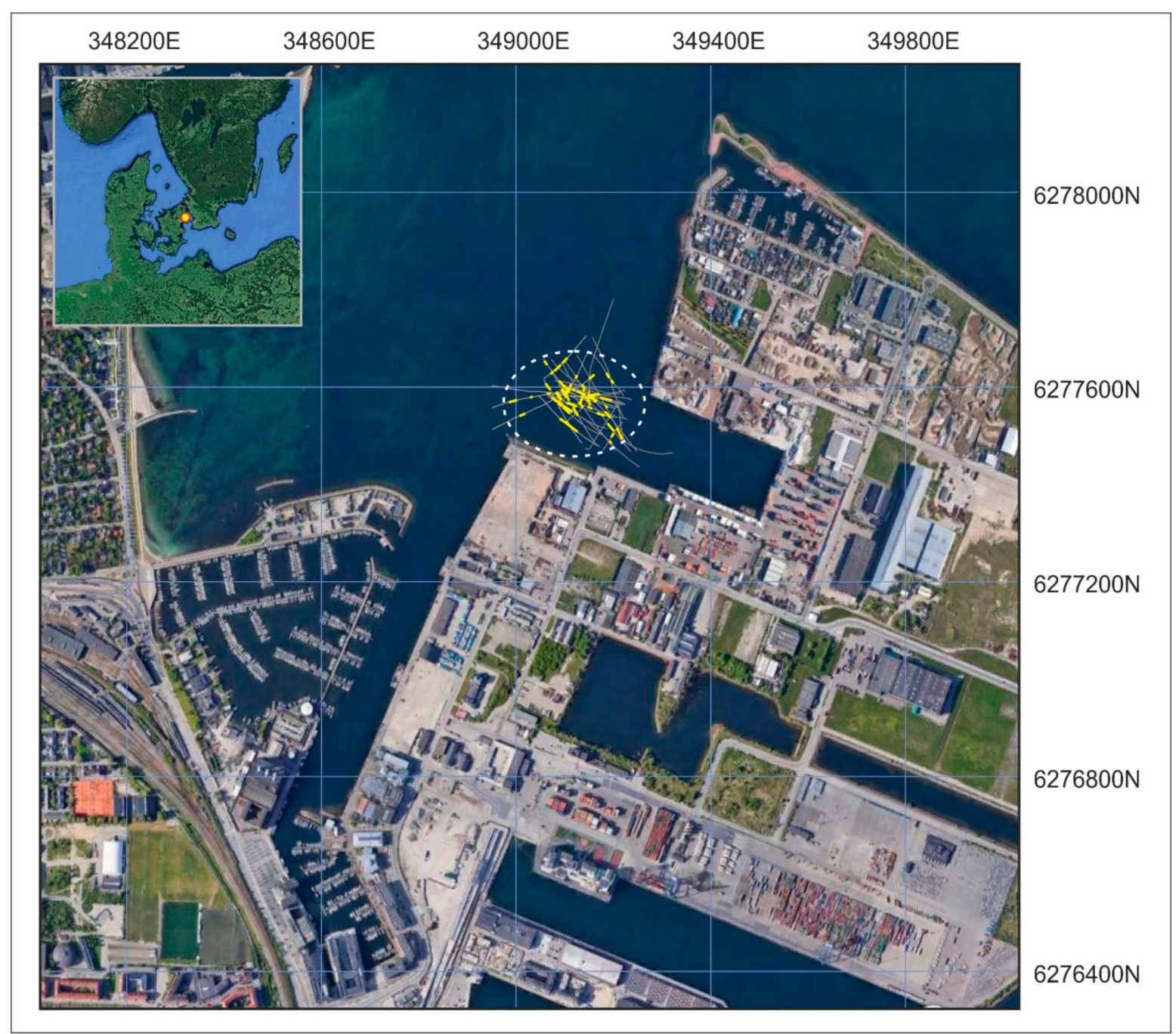

Figure 17. Map of the acoustic anomaly in Svanemøllen Harbour, Copenhagen, Denmark. The sailing lines are grey, the response features (haystacks and narrow noise columns) are yellow. Zone 33 UTM coordinates. Graphics: Grøn.

In a couple of cases at the Svanemøllen Harbour site, clear haystack features in transverse profiles appear as single or a few parallel narrow noise columns in the profiles cutting them approximately at right angles. A good example is seen at UTM z33 position $349132 \mathrm{E} / 6177576 \mathrm{~N}$, where the profiles 21 (NNW-SSE orientated) and 27 (NNE-SSW orientated) cut each other. While profile 21 produced a clear and significant haystack in the actual position (Figure 18A), this feature in the intersecting profile 27 appears as a quite weak narrow noise column (Figure 18B). Consequently, this underpins the assumption that haystacks consist of concentrations of narrow noise columns. 


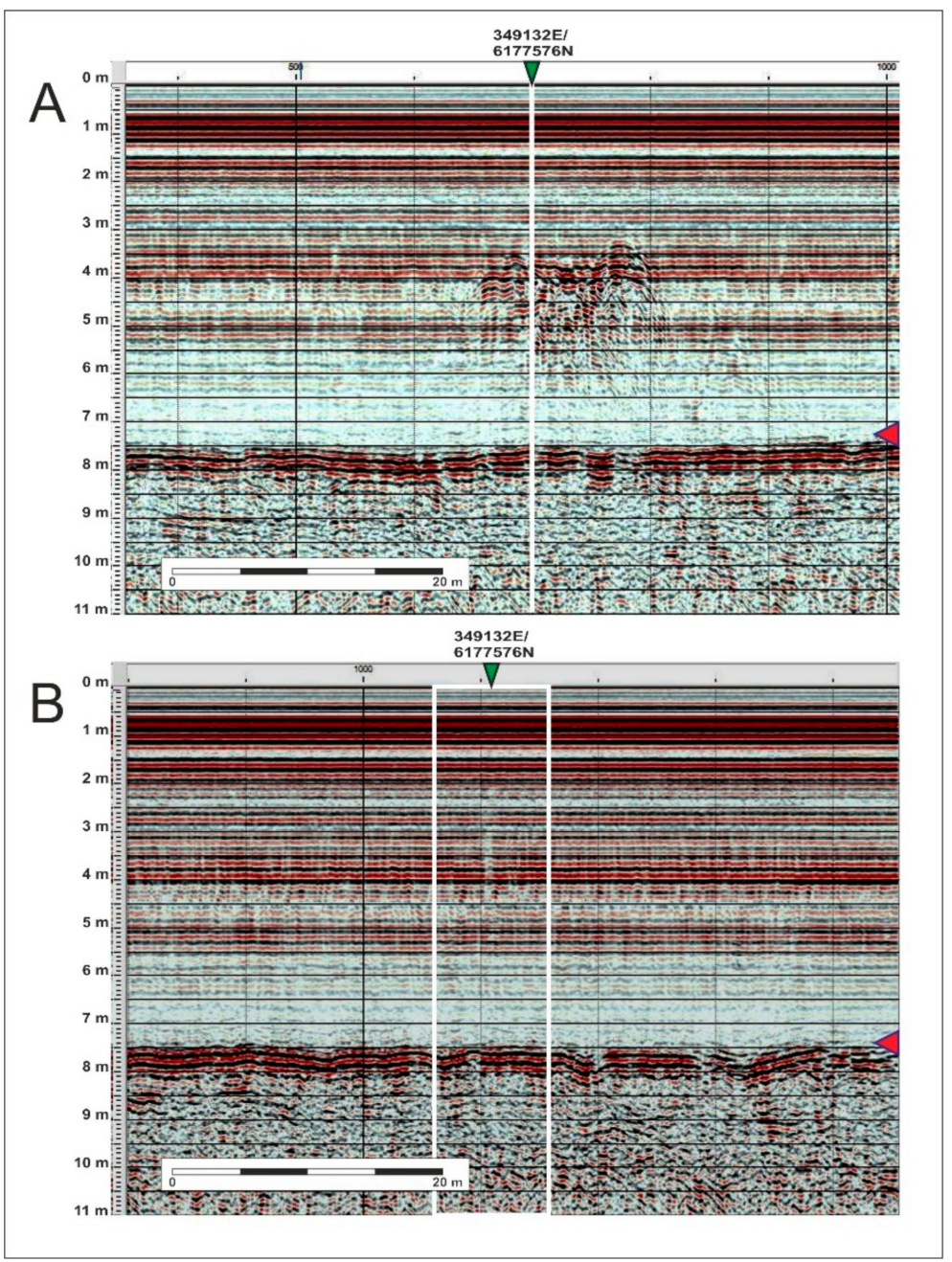

Figure 18. (A): Profile 21 showing a clear haystack feature around its intersection with profile 27 at point 349132E/6177576N (shown with a green arrow above). (B): A section of profile 27 displaying a weak and narrow noise column at its intersection with profile 21 at point 349132E/6177576N (marked with a green arrow above and a white frame). Seafloor marked with red arrow to the right. Depth scale to the left. UTM 33 coordinates. Graphics: Grøn.

\section{Conclusions}

According to the work carried out so far, an early development stage HALD approach to mapping of submerged sites has been successfully tested in various places in Europe, the Middle East and USA. Its apparent ability to detect responses from knapped lithic pieces points to a significantly better identification rate of Stone Age sites under water than previously possible and even better than what is possible on land. Further refinement of this method will help to ensure less irreversible damage to such sites during commercial offshore activities. While results appear promising thus far, more field and laboratory tests are needed to understand more nuanced aspects of the application of HALD to a greater variety of site types and environmental settings.

While it is rather easy to ground-truth sites with material exposed on the seafloor, it can be quite demanding to verify cultural layers embedded in sediments without undertaking a costly and time-consuming investigation. A central problem is that our current understanding of the acoustic responses from knapped lithics does not enable us to estimate precisely how deep they are located in the sediments. Several strategies or mitigating this problem are under consideration and will be tested in the near future. 
The HALD approach has been demonstrated to excite and register acoustic responses from such a wide variety of knappable materials, that there is reason for optimism with regard to its general application to materials knapped by humans in prehistory (Table 2).

The HALD approach has also demonstrated a surprising ability to excite and register acoustic responses from knapped lithics covered by meters of seafloor sediment. This will hopefully allow the HALD method to not just identify surface sites, whose context may be uncertain, but also intact, buried sites. It is the expectation of the authors that the HALD approach by enhancing the visibility of the submerged Stone Age sites can contribute to a full appreciation of the potential of the preserved Stone Age sites and Stone Age environments under water.

It is believed that the HALD approach will be able to improve the efficiency of the mapping of submerged Stone Age sites significantly in comparison with the topographically based modelling approaches employed today.

Author Contributions: Investigation, O.G., L.O.B., M.F.S., S.J., A.M., N.B., D.C., B.N., A.S. and E.G. Experiments, R.T.B., B.M., E.N., C.H., Q.R. and P.B. Methodology and legal supervision, X.G., P.S. and A.D. All authors have read and agreed to the published version of the manuscript.

Funding: The survey at Atlit-Yam, Israel, (IAA permit S-688/2016) was supported by the Israel Science Foundation (grant No. 1899/12). The National Center for the Preservation of Technology and Training and Florida Division of Historical Resources, supported the work in USA with grant numbers P19AP00136 and 20.h.sm.200.155, respectively.

Institutional Review Board Statement: Not Applicable.

Informed Consent Statement: Not Applicable.

Data Availability Statement: Not Applicable.

Acknowledgments: Thanks to those who assisted with the fieldwork. Peer T. Jørgensen, Department of Geosciences and Natural Resource Management, Copenhagen, assisted the group's fieldwork in Europe as a technician. Paul Christiansen and Mathias Madsen, Department of Geosciences and Natural Resource Management assisted with the fieldwork in Denmark. Amir Yurman and Moshe Bachar from the maritime workshop of the Leon Recanati Institute for Maritime Studies, Haifa, assisted with the fieldwork in Israel. Timothy DeSmet, Binghamton University, gave insight to labwork in the USA. Thanks to Schlumberger for the Petrel university grant issued to the Department of Geosciences and Natural Resource Management, Geology Group, University of Copenhagen, and thanks to the Wellbore Acoustic Lab at Texas A\&M University for initial acoustic experiments.

Conflicts of Interest: The authors declare no conflict of interest.

\section{References}

1. Benjamin, J.; Rovere, A.; Fontana, A.; Furlani, S.; Vacchi, M.; Inglis, R.H.; Galili, E.; Antonioli, F.; Sivan, D.; Miko, S.; et al. Late Quaternary sea-level changes and early human societies in the central and eastern Mediterranean Basin: An interdisciplinary review. Quat. Int. 2017, 449, 29-57. [CrossRef]

2. Brenna, J.T.; Carlson, S.E. Docosahexaenoic acid and human brain development: Evidence that a dietary supply is needed for optimal development. J. Hum. Evol. 2014, 77, 99-106. [CrossRef] [PubMed]

3. Cortés-Sánchez, M.; Morales-Muñiz, A.; Simón-Vallejo, M.D.; Lozano-Francisco, M.C.; Vera-Peláez, J.L.; Finlayson, C.; RodriguezVidal, J.; Delgado-Huertas, A.; Jiménez-Espejo, F.J.; Martínez-Ruiz, F.; et al. Earliest Known Use of Marine Resources by Neanderthals. PLoS ONE 2011, 6, e24026. Available online: https://journals.plos.org/plosone/article?id=10.1371/journal.pone. 0024026 (accessed on 17 November 2020). [CrossRef] [PubMed]

4. Crawford, M. Long-chain polyunsaturated fatty acids in human evolution. In Human Brain Evolution; Cunnane, S.C., Stewart, K.M., Eds.; Wiley and Sons: Hoboken, NJ, USA, 2010; pp. 13-31.

5. Erlandson, J.M.; Braje, T.J. Coasting out of Africa: The potential of mangrove forests and marine habitats to facilitate human coastal expansion via the Southern Dispersal Route. Quat. Int. 2015, 382, 31-41. [CrossRef]

6. Fischer, A.; Clemmesen, L.B.; Donahue, R.; Heinemeier, J.; Lykke-Andersen, H.; Lysdahl, P.; Mortensen, M.F.; Olsen, J.; Petersen, P.V. Late Palaeolithic Nørre Lyngby-A northern outpost close to the west coast of Europe. Quartär 2013, 60, 137-162.

7. Kyriacou, K.; Parkington, J.E.; Marais, A.D.; Braun, D.R. Nutrition, modernity and the archaeological record: Coastal resources and nutrition among Middle Stone Age hunter-gatherers on the western Cape coast of South Africa. J. Hum. Evol. 2014, 77, 64-73. [CrossRef] 
8. Ramos, J.; Domíguez-Bella, S.; Cantillo, J.J.; Soriguer, M.; Pérez, M.; Hernando, J.; Vijande, E.; Zabala, C.; Clemente, I.; Bernal, D. Marine resources exploitation by Palaeolithic hunter-fisher-gatherers and Neolithic tribal societies in the historical region of the Strait of Gibraltar. Quat. Int. 2011, 239, 104-113. [CrossRef]

9. Richards, M.P.; Jacobi, R.; Cook, J.; Pettitt, P.B.; Stringer, C.B. Isotope evidence for the intensive use of marine foods by Late Upper Palaeolithic humans. J. Hum. Evol. 2005, 49, 390-394. [CrossRef]

10. Will, M.; Kandel, A.W.; Kyriacou, K.; Conard, N.J. An evolutionary perspective on coastal adaptations by modern humans during the Middle Stone Age of Africa. Quat. Int. 2016, 404, 68-86. [CrossRef]

11. Gallagher, W.B.; Parris, D.C.; Smith Grandstaff, B.; DeTample, C. Quaternary Mammals from the Continental Shelf off New Jersey. Mosasaur J. Del. Val. Paleontol. Soc. 1989, 4, 101-110.

12. Harris, P.T.; Macmillan-Lawler, M.; Rupp, J.; Baker, E.K. Geomorphology of the oceans. Mar. Geol. 2014, 352, 4-24. [CrossRef]

13. Joy, S. Coastally-adapted: A developing model for coastal Paleoindian sites on the North American eastern continental shelf. J. Island Coast. Archaeol. 2020, 1-20. [CrossRef]

14. Odum, E.; Barrett, G.W. Fundamentals of Ecology; Cengage Learning: Boston, MA, USA, 2005.

15. Waelbroeck, C.; Labeyrie, L.; Michel, E.; Duplessy, J.C.; McManus, J.F.; Lambeck, K.; Balbon, E.; Labracherie, M. Sea-level and deep water temperature changes derived from benthic foraminifera isotopic records. Quat. Sci. Rev. 2002, 21, 295-305. [CrossRef]

16. Flemming, N.C.; Harff, J.; Moura, D. Non-Cultural Processes of Site Formation, Preservation and Destruction. In Submerged Landscapes of the European Continental Shelf; Flemming, N.C., Harff, J., Moura, D., Burgess, A., Bailey, G.N., Eds.; Wiley Blackwell: Oxford, UK, 2017; pp. 51-82.

17. Flemming, N.C.; Çă̆atay, M.N.; Chiocci, F.L.; Galanidou, N.; Lericolais, G.; Jöns, H.; Missiaen, T.; Moore, F.; Rosentau, A.; Sakellariou, D.; et al. Land Beneath the Waves Submerged Landscapes and Sea Level Change. A Joint Geoscience-Humanities Strategy for European Continental Shelf Prehistoric Research; European Marine Board Position Papernr. 21. 2014 , p. 175. Available online: http:/ / www.marineboard.eu/sites/marineboard.eu/files/public/publication/Land\%20beneath\%20the\%20 waves-253.pdf (accessed on 12 November 2020).

18. Faught, M.K. Submerged Paleoindian and Archaic Sites of the Big Bend, Florida. J. Field Archaeol. 2004, 29, 273-290. [CrossRef]

19. Glimmerveen, J.; Mol, D.; Post, K.; Reumer, J.W.F.; van der Plicht, H.; de Vos, J.; van Reenen, G.; Pals, J.P. The North Sea Project: The First Palaeontological, Palynological and Archaeological Results. In Submarine Prehistoric Archaeology of the North Sea. Research Priorities and Collaboration with Industry; CBA Research Report; nr. 141; Flemming, N.C., Ed.; English Heritage/Council for British Archaeology: York, UK, 2004; pp. 43-52.

20. Parfitt, S.A.; Barendregt, R.W.; Breds, M.; Collins, M.J.; Coope, G.R.; Durbridge, P.; Field, M.H.; Lee, J.R.; Lister, A.M.; Mutch, R.; et al. The earliest record of human activity in northern Europe. Nature 2005, 438, 1008-1012. [CrossRef]

21. Parfitt, S.A.; Ashton, N.M.; Lewis, S.G.; Abel, R.L.; Russell, C.G.; Field, M.H.; Gale, R.; Hoare, P.G.; Larkin, N.R.; Lewis, M.D.; et al. Early Pleistocene human occupation at the edge of the boreal zone in northwest Europe. Nature 2010, 466, 229-233. [CrossRef]

22. Davis, L.G.; Madsen, D.B.; Becerra-Valdivia, L.; Higham, T.; Sisson, D.A.; Skinner, S.M.; Stueber, D.; Nyers, A.J.; Keen-Zebert, A.; Neudorf, C.; et al. Late Upper Paleolithic occupation at Cooper's Ferry, Idaho, USA, 16,000 years ago. Science 2019, 365, 891-897. [CrossRef]

23. Dillehay, T.D.; Ramírez, C.; Pino, M.; Collins, M.B.; Rossen, J.; Pino-Navarro, J.D. Monte Verde: Seaweed, Food, Medicine, and the Peopling of South America. Science 2008, 320, 784-786. [CrossRef]

24. Erlandson, J.M.; Rick, T.C.; Braje, T.J.; Casperson, M.; Culleton, B.; Fulfrost, B.; Garcia, T.; Guthrie, D.A.; Jew, N.; Kennett, D.J.; et al. Paleoindian Seafaring, Maritime Technologies, and Coastal Foraging on California's Channel Islands. Science 2011, $331,1181$. [CrossRef]

25. Grøn, O. Mammoth-hunter Camps in the Scandinavian North Sea Sector during the Late Weichselian? Vestn. Saint Petersbg. Univ. 2019, 64, 555-583. [CrossRef]

26. Halligan, J.; Waters, M.R.; Perrotti, A.; Owens, I.J.; Feinberg, J.M.; Bourne, M.D.; Fenerty, B.; Winsborough, B.; Carlson, D.; Fisher, D.C.; et al. Pre-Clovis occupation 14,550 years ago at the Page-Ladson site, Florida, and the peopling of the Americas. Sci. Adv. 2016, 2, e1600375. [CrossRef] [PubMed]

27. Pedersen, M.W.; Ruter, A.; Schweger, C.; Friebe, H.; Staff, R.A.; Kjeldsen, K.K.; Mendoza, M.L.Z.; Beaudoin, A.B.; Zutter, C.; Larsen, N.K.; et al. Postglacial viability and colonization in North America's ice-free corridor. Nature 2016, 537, 45-49. [CrossRef] [PubMed]

28. Waters, M.R.; Forman, S.L.; Jennings, T.A.; Nordt, L.C.; Driese, S.G.; Feinberg, J.M.; Keene, J.L.; Halligan, J.; Lindquist, A.; Pierson, J.; et al. The Buttermilk Creek Complex and the Origins of Clovis at the Debra L. Friedkin Site, Texas. Science 2011, 331, 1599-1603. [CrossRef] [PubMed]

29. Stanford, D.; Lowery, D.; Jodry, M.; Bradley, B.A.; Kay, M.; Stafford, T.W.; Speakman, R.J. New Evidence for a Possible Paleolithic Occupation of the Eastern North American Continental Shelf at the Last Glacial Maximum. In Prehistoric Archaeology on the Continental Shelf: A Global Review; Evans, A.M., Flatman, J.C., Flemming, N.C., Eds.; Springer: New York, NY, USA, 2014; pp. 73-93.

30. Waters, M.R. Late Pleistocene exploration and settlement of the Americas by modern humans. Science 2019, 365 , eaat5447. [CrossRef]

31. Braje, T.J.; Dillehay, T.D.; Erlandson, J.M.; Klein, R.G.; Rick, T.C. Finding the first Americans. Science 2017, 358, 592-594. [CrossRef] [PubMed] 
32. Dixon, E.J. Bones, Boats, and Bison: Archaeology and the First Colonization of Western North America; The University of New Mexico Press: Albuquerque, NM, USA, 1999.

33. Faught, M.K. Where was the PaleoAmerind standstill? Quat. Int. 2017, 444, 10-18. [CrossRef]

34. Mandryk, C.A.S.; Josenhans, H.; Fedje, D.W.; Mathewes, R.W. Late Quaternary paleoenvironments of Northwestern North America: Implications for inland versus coastal migration routes. Quat. Sci. Rev. 2001, 20, 301-314. [CrossRef]

35. Sutton, P. The Pulsating Hearth: Large Scale Cultural and Demographic Processes in Aboriginal Australia. In Hunter-Gatherer Demography. Past and Present; Meehan, B., White, N., Eds.; University of Sydney: Sydney, Australia, 1990; pp. 71-80.

36. Bailey, G.; Galanidou, N.; Peeters, H.; Jöns, H.; Mennega, M. The Archaeology of Europe's Drowned Landscapes: Introduction and Overview. In The Archaeology of Europe's Drowned Landscapes; Bailey, G., Galanidou, N., Peeters, H., Jöns, H., Mennega, M., Eds.; Springer Nature: Cham, Switzerland, 2020; pp. 1-23.

37. Grøn, O. Some problems with modelling the positions of prehistoric hunter-gatherer settlements on the basis of landscape topography. J. Archaeol. Sci. Rep. 2018, 20, 192-199. [CrossRef]

38. Grøn, O.; Hansson, A.; Cook Hale, J.; Phillips, C.; Zander, A.; Gross, D.; Nilsson, B. Mapping Cultural Heritage sites by means of topographical modelling. In The SPRINGER Handbook of Cultural Heritage Analysis; Springer: Berlin, Germany, in press.

39. Mackie, Q.; Davis, L.; Fedje, D.; McLaren, D.; Gusick, E.A. Locating Pleistocene-age Submerged Archaeological Sites on the Northwest Coast: Current Status of Research and Future Directions. In Paleoamerican Odyssey; Graf, K.E., Ketron, C.V., Waters, M.R., Eds.; Center for the Study of the First Americans, Texas A\&M University: College Station, TX, USA, 2013 ; pp. $133-147$.

40. O'Shea, J.M.; Lemke, A.K.; Sonnenburg, E.P.; Reynolds, R.G.; Abbott, B.D. A 9,000-year-old caribou hunting structure beneath Lake Huron. Proc. Natl. Acad. Sci. USA 2014, 111, 6911-6915. [CrossRef]

41. Grøn, O.; Boldreel, L.O.; Hermand, J.-P.; Rasmussen, H.; Dell'Anno, A.; Cvikel, D.; Galili, E.; Madsen, B.; Nørmark, E. Detecting human-knapped flint with marine high-resolution reflection seismics: A preliminary study of new possibilities for subsea mapping of submerged Stone Age sites. Underw. Technol. 2018, 35, 35-49. [CrossRef]

42. Grøn, O.; Boldreel, L.O.; Tayong Boumda, R.; Blondel, P.; Madsen, B.; Nørmark, E.; Cvikel, D.; Galili, E.; Dell'Anno, A. Acoustic detection and mapping of submerged Stone Age sites with knapped flint. In The SPRINGER Handbook of Cultural Heritage Analysis; Springer: Berlin, Germany, in press.

43. Pandey, V.; Holm, S. Connecting the grain-shearing mechanism of wave propagation in marine sediments to fractional order wave equations. J. Acoust. Soc. Am. 2016, 140, 4225-4236. [CrossRef] [PubMed]

44. Bordes, F. Ètudes comparative des différentes techniques de débitage et de typologie du Paléolithique ancien et moyen. L'Anthropolgie 1947, 54, 19-34.

45. Shackley, M.S. The Stone Tool Technology of Ishi and the Yana. In Ishi in Three Centuries; Kroeber, K., Kroeber, C., Eds.; University of Nebraska Press: Lincoln, NE, USA, 2003; pp. 159-200.

46. Madsen, B. Late Palaeolithic Cultures of South Scandinavia-Tools, Traditions and Technology. In The Earliest Settlement of Scandinavia, and Its Relationship with Neighbouring Areas; Larsson, L., Ed.; Acta Archaeologica Lundensia. Series in $8^{\circ}$ Minore, No 24; Almquist \& Wiksel: Stockholm, Sweden, 1996; pp. 61-74.

47. Tixier, J.; Inizian, M.L.; Roche, H. Préhistoire de la Pierre Tallée; C.R.E.P: Antibes, France, 1980.

48. Yule, P.; Bemman, M. Klangsteine aus Orissa. Die frühesten Musikinstrumente Indiens? Archaeol. Music. 1988, 1, 1-7.

49. Rothberg, S.J.; Allen, M.S.; Castellini, P.; Di Maio, D.; Dirckx, J.J.J.; Ewins, D.J.; Halkon, B.J.; Muyshondt, P.; Paone, N.; Ryan, T.; et al. An international review of laser Doppler vibrometer: Making light work of vibration measurement. Opt. Lasers Eng. 2017, 99, 11-22. [CrossRef]

50. Sinha, D.N. Acoustic resonance spectroscopy (ARS). IEEE Potentials 1992, 11, 10-13. [CrossRef]

51. Hermand, J.-P.; Grøn, O.; Asch, M.; Ren, Q. Modelling flint acoustics for detection of submerged Stone Age sites. IEEE Xplore 2011, 9. [CrossRef]

52. Ren, Q.; Grøn, O.; Hermand, J.-P. On the in-situ detection of flint for underwater Stone Age archaeology. IEEE Xplore 2011, 7. [CrossRef]

53. Hermand, J.-P.; Tayong, R. Geoacoustic characterization of Stone Age cultural layers: Preliminary FE modelling. In Proceedings of the MTS/IEEE OCEANS-Bergen, Bergen, Norway, 10-14 June 2013; p. 6. [CrossRef]

54. Grøn, O.; Boldreel, L.O.; Hermand, J.-P.; Rasmussen, H.; Dell'Anno, A.; Cvikel, D.; Galili, E.; Madsen, B.; Nørmark, E. Mapping Submerged Stone Age Sites Using Acoustics: Some Experimental Results. In IKUWA6, Shared Heritage: Proceedings of the Sixth International Congress for Underwater Archaeology 28 November-2 December 2016; Rodrigues, J.A., Traviglia, A., Eds.; Western Australian Maritime Museum Fremantle: Fremantle, Australia; Archaeopress: Oxford, UK, 2016; pp. 309-314.

55. Galili, E.; Rosen, B. Submerged Neolithic Settlements off the Carmel Coast, Israel: Cultural and environmental insights. In Submerged Prehistory; Benjamin, J., Bonsall, C., Pickard, C., Fischer, A., Eds.; Oxbow Books: Oxford, UK, 2011 ; pp. $272-286$.

56. Skaarup, J.; Grøn, O. Møllegabet II. A Submerged Mesolithic Settlement in Southern Denmark; BAR International Series 1328; Archaeopress: Oxford, UK, 2004.

57. Joy, S. The Trouble with the Curve: Re-Evaluating the Gulf of Mexico Sea Level Curve. Quat. Int. 2019, 525, 103-113. [CrossRef]

58. Austin, R.J.; Upchurch, S.B.; Dunbar, J.S.; Estabrook, R.W.; Endonino, J.C.; Burke, A.M. The Quarry Cluster Approach to Chert Provenance: A Review of the Method with Examples from Early Florida Sites. In Early Human Life on the Southeastern Coastal Plain; Goodyear, A.C., Moore, C.R., Eds.; University of Florida Press: Gainsville, FL, USA, 2018; pp. $108-123$. 
59. Tanner, B.R.; Work, K.A.; Evans, J.M. The Potential of Organic Sediments in Florida Spring Runs as Records of Environmental Change. Southeast. Geographer. 2020, 60, 200-214. [CrossRef]

60. Smith, M.F. Hunting an Underwater Mammoth: A Re-Evaluation of the First Submerged Prehistoric Site Excavated in the Americas. In New Directions in the Search for the First Floridians; Thulman, D.K., Garrison, E., Eds.; University Press of Florida: Gainesville, FL, USA, 2019; pp. 79-98.

61. Sørensen, S.A. Projekt Blak. Beretning om Undersøgelserne på den Submarine Kongemoseboplads ved Blak. Report; Egnsmuseet Færgegården: Frederikssund, Denmark, 1990.

62. Sørensen, S.A. Kongemosekulturen I Sydskandinavien; Egnsmuseet Færgegården: Frederikssund, Denmark, 1996.

63. Agger, G.; Suadacani, H. Den Geologiske Undersøgelse i Forbindelse med den Arkæologiske Udgravning ved Blak i Roskilde Fjord; Preliminary Report; Roskilde University Center: Roskilde, Denmark, 1990.

64. Altorfer, K.; Conscience, A.-K. Meilen-Schellen. Die neolithischen und Spätbronzezeitlichen Funde und Befunde der Untersuchungen 1934-1996; Seeufersiedlungen. Zürcher Archäologie Heft 18; Baudirektion Kanton Zürich, Hochbauamt Kantonsarchäologie: Zürich, Switzerland, 2005.

65. Kienholtz, A.; Affolter, J. VII Silices. In Zürich-Parkhaus Opéra. Eine Neolithische Feuchtbodenfundstelle; Band 2: Funde; Harb, C., Bleicher, N., Eds.; Monograph der Kantonsarchäologie Zürich: Zürich, Switzerland, 2016; Volume 49, pp. 109-138.

66. Bennström, G.; Norell, M.L.; Wehlin, J. Jägare och samlare. Dalarnas Hembygdsb. 2016, 86, 105-140.

67. Norell, M.L.; Wehlin, J. Dalarne. Dalarnas Hembygdsb. 2016, 86, 17-40. 